\title{
Effects of nitrate and phosphate supply on chromophoric and fluorescent dissolved organic matter in the Eastern Tropical North Atlantic: a mesocosm study
}

\author{
A. N. Loginova, C. Borchard, J. Meyer, H. Hauss, R. Kiko, and A. Engel \\ GEOMAR Helmholtz-Centre for Ocean Research Kiel, Düsternbrooker Weg 20, 24105 Kiel, Germany
}

Correspondence to: A. N. Loginova (aloginova@geomar.de)

Received: 24 April 2015 - Published in Biogeosciences Discuss.: 18 May 2015

Revised: 22 October 2015 - Accepted: 10 November 2015 - Published: 2 December 2015

\begin{abstract}
In open-ocean regions, as is the Eastern Tropical North Atlantic (ETNA), pelagic production is the main source of dissolved organic matter (DOM) and is affected by dissolved inorganic nitrogen (DIN) and phosphorus (DIP) concentrations. Changes in pelagic production under nutrient amendments were shown to also modify DOM quantity and quality. However, little information is available about the effects of nutrient variability on chromophoric (CDOM) and fluorescent (FDOM) DOM dynamics. Here we present results from two mesocosm experiments ("Varied P" and "Varied N") conducted with a natural plankton community from the ETNA, where the effects of DIP and DIN supply on DOM optical properties were studied. CDOM accumulated proportionally to phytoplankton biomass during the experiments. Spectral slope $(S)$ decreased over time indicating accumulation of high molecular weight DOM. In Varied N, an additional CDOM portion, as a result of bacterial DOM reworking, was determined. It increased the CDOM fraction in DOC proportionally to the supplied DIN. The humic-like FDOM component (Comp.1) was produced by bacteria proportionally to DIN supply. The protein-like FDOM component (Comp.2) was released irrespectively to phytoplankton or bacterial biomass, but depended on DIP and DIN concentrations. Under high DIN supply, Comp.2 was removed by bacterial reworking, leading to an accumulation of humiclike Comp.1. No influence of nutrient availability on amino acid-like FDOM component in peptide form (Comp.3) was observed. Comp. 3 potentially acted as an intermediate product during formation or degradation of Comp.2. Our findings suggest that changes in nutrient concentrations may lead to substantial responses in the quantity and quality of optically active DOM and, therefore, might bias results of the applied
\end{abstract}

in situ optical techniques for an estimation of DOC concentrations in open-ocean regions.

\section{Introduction}

Dissolved organic matter (DOM) is the largest dynamic pool of organic carbon in the ocean. Its global inventory comprises of approximately 662 pentagrams of carbon $(\mathrm{PgC}$; Hansell et al., 2009). Labile and semi-labile high molecular weight (HMW) DOM is released primarily by phytoplankton (Carlson and Hansell, 2015). It is used as substrate by heterotrophic communities, which, in turn, release less bioavailable semi-refractory or even refractory DOM, thereby modifying the quantity and quality of the DOM pool (Azam et al., 1983; Ogawa et al., 2001; Jiao et al., 2010). Therefore, natural DOM is a complex mixture of organic compounds with different characteristics, such as molecular structure and molecular weight, resulting in different optical properties (Stedmon and Nelson, 2015).

For instance, the presence of conjugated double bonds (polyenes) results in the absorption of light in the UV and visible wavelengths (Stedmon and Álvarez-Salgado, 2011). The light absorbing DOM fraction is referred to as "chromophoric" or "colored" DOM (CDOM; Coble, 2007). Due to its abilities to absorb in a wide wavelength range, CDOM may protect primary producers from harmful UV irradiation in the water column, but may also reduce photosynthetically active radiation, as it absorbs at a similar wavelength to the first chlorophyll absorption maximum $(\sim 443 \mathrm{~nm}$; Zepp et al., 2008). Photons, absorbed by CDOM, may induce the 
formation of free radicals, which by colliding with other molecules or other radicals produce new organic molecules, reducing metals or introducing short inorganic and organic substances as byproducts (Sulzberger and Durisch-Kaiser, 2009). Modified by photoreactions, CDOM may serve as biological substrates for auto- and heterotrophic communities, by releasing nutrients and low molecular weight (LMW) organic compounds, as well as a source of trace gases (e.g., $\mathrm{CO}, \mathrm{CO}_{2}$; Kieber et al., 1990, 1999; Moran and Zepp, 1997).

CDOM absorption has often been used as an indicator for dissolved organic carbon (DOC) concentrations in the Ocean (Fichot and Benner, 2011, 2012; Rochelle-Newall et al., 2014). For example, DOC concentration in estuarine surface waters can be derived from CDOM absorption by remotesensing techniques, assuming a direct relationship between CDOM absorption and DOC concentrations (Del Castillo, 2007). In the open ocean, however, this relationship varies throughout the water column (Nelson and Siegel, 2013), and factors affecting it are poorly understood.

A better knowledge on factors influencing the CDOM/DOC relationship could improve our understanding of DOM cycling, as well as of the regulation of light attenuation in the ocean. Furthermore, the knowledge of the factors influencing the open-ocean CDOM/DOC relationship would be useful for the estimation of DOC concentrations from CDOM absorption measurements by remote-sensing techniques.

As CDOM embodies a complex mixture of organic compounds that have overlapping absorption spectra with, generally, no single compound dominating (Del Vecchio and Blough, 2004), CDOM absorbance spectra decrease exponentially toward a longer wavelength with no discernible peaks. Therefore, the CDOM concentration is commonly expressed as absorption coefficient at a chosen wavelength (e.g., 325, 355, $375 \mathrm{~nm}$; Stedmon and Markager, 2001; Fichot and Benner, 2012; Nelson and Siegel, 2013).

To derive information on CDOM quality, such as molecular weight and modification processes, spectral slopes $(S)$ of CDOM light absorption and spectral slopes ratio $\left(S_{\mathrm{R}}\right)$ are used (Helms et al., 2008; Zhang et al., 2009). It has been shown that $S$ decreases with increasing DOM molecular weight, and, therefore, may be used as an indicator of accumulation/degradation of bioavailable HMW-DOM (De Haan and De Boer, 1987; Helms et al., 2008; Zhang et al., 2009).

The ratio of $S$ at wavelength region $275-295 \mathrm{~nm}$ $\left(S_{275-295}\right)$ to $S$ at $350-400 \mathrm{~nm}\left(S_{350-400}\right), S_{\mathrm{R}}$, is used to estimate CDOM transformation processes. $S_{\mathrm{R}}$ increases as CDOM becomes involved in photoreactions and decreases as CDOM undergoes microbial reworking (Helms et al., 2008).

The presence of aromatic rings in CDOM often also results in fluorescence (Stedmon and Álvarez-Salgado, 2011). Fluorescent DOM (FDOM) excitation/emission (Ex/Em) spectra allow discriminating between different pools of CDOM (Coble, 2007; Stedmon and Bro, 2008; Mopper et al., 2007;
Yamashita et al., 2010). The substances that are excited and emit in the UV spectral range commonly correspond to labile proteinaceous DOM, and therefore are referred to as amino acid-like (tyrosine- and tryptophan-like) FDOM (e.g., Coble, 1996). The substances that are excited in the UV spectral range, but emit in the visible spectral range were identified as fulvic- and humic-like FDOM (Gueguen and Kowalczuk, 2013). Tyrosine- and tryptophan-like substances have been used for the assessment of in situ primary productivity, while humic-like substances are used for the indication of allochthonous (e.g., riverine) DOM or microbial DOM transformation (Coble, 1996).

Although the CDOM and FDOM distribution and cycling has been described for many open-ocean sites (Jørgensen et al., 2011; Kowalczuk et al., 2013; Nelson and Siegel, 2013), specific sources and factors influencing their composition and transformations are not yet well understood.

For example, CDOM accumulation is often related to nutrient remineralization (Swan et al., 2009; Nelson and Siegel, 2013). However, the effects of nutrient variability on CDOM concentration and on the relationship between CDOM and DOC are largely understudied.

Stedmon and Markager (2005) have reported that nutrients affect freshly produced marine FDOM pools in temperate climate conditions (Raunefjord, Norway). In their study, the amino acid-like fluorescence was enhanced under phosphate (P) and silica limitation, but was independent from phytoplankton composition. Bacterially produced humic-like FDOM components were reported to accumulate under P and silica limitation as well. Later, by addition of different synthetic dissolved organic and inorganic nitrogen $(\mathrm{N})$ substrates to microbial incubations, Biers et al. (2007) emphasized the role of $\mathrm{N}$ in CDOM accumulation. They showed that CDOM and FDOM production by bacteria, cultured in natural seawater medium, can be affected to a different degree by the chemical composition and steric effects of the organic $\mathrm{N}$ source, while inorganic $\mathrm{N}$ sources do not contribute significantly to CDOM or FDOM accumulation. On the other hand, Kramer and Herndl (2004) demonstrated that bacteria may be able to transform about $30 \%$ of taken up inorganic $\mathrm{N}$ into semi-labile to refractory humic DOM.

Stedmon and Markager (2005), however, revealed some doubts about a setup of P limitation. Besides, Kramer and Herndl (2004) and Biers et al. (2007) were based on single bacterial cultures, and phytoplankton and net-effects, associated with natural aquatic bacterial community, were excluded. Therefore, the influence of inorganic nutrients on CDOM concentration and FDOM components in natural waters remains to be resolved.

In the open-ocean regions, as is the Eastern Tropical North Atlantic (ETNA), pelagic production of DOM is, supposedly, of greater importance than terrestrial DOM input (e.g., Coble et al., 2007).

In classical view, the ETNA is considered an "excess N" region compared to the "Redfield N : P ratio" of 16 (see Red- 
field, 1958 and Gruber and Sarmento, 1997) reflecting high rates of biological N-fixation due to Saharan dust deposition, with $\mathrm{N}: \mathrm{P}$ ratios of $16-25$ at depth (see Fanning, 1992). It features a shallow oxygen minimum zone (OMZ) at about $100 \mathrm{~m}$ depth with oxygen concentrations of about $60 \mu \mathrm{mol}$ $\mathrm{O}_{2} \mathrm{~kg}^{-1}$ (Brandt et al., 2015) and a deeper OMZ at approximately 300-600 m depth with oxygen concentrations up to $40 \mathrm{O}_{2} \mu \mathrm{mol} \mathrm{kg}{ }^{-1}$ (Karstensen et al., 2008). However, eddies originating in the Mauritanian upwelling regime and propagating westward can harbor much lower oxygen concentrations ( $\sim 4 \mu \mathrm{mol} \mathrm{O} \mathrm{kg}^{-1}$; Karstensen et al., 2015), potentially enabling N-loss processes (Strous et al., 2006; Kartal et al., 2007; Jetten et al., 2009; Jayakumar et al., 2009). Those mesoscale eddies may transport nutrient loaded but relatively $\mathrm{N}$-deficient waters to the surface (McGillicudy et al., 2003, 2007; Mathis et al., 2007). Furthermore, it has been shown that non-diazotroph primary production in the surface waters of ETNA can be N-limited (Franz et al., 2012; Hauss et al., 2013).

Here we investigated the effects of different dissolved inorganic nitrogen (DIN) and dissolved inorganic phosphorous (DIP) concentrations and of their supply ratio (DIN : DIP) on DOM quantity and quality by using spectroscopic methods of DOM analysis (e.g., accumulation and properties of CDOM and FDOM) during a mesocosm study with natural pelagic community off the Cape Verdean Archipelago, an area affected by low oxygen-core eddies.

During these mesocosm experiments, we tested whether (1) pelagic production is a source of CDOM and FDOM, (2) CDOM and FDOM accumulation and composition are affected by changes in nutrient stoichiometry, and whether (3) the relationship between CDOM absorption and DOC concentrations is stable under variable nutrient concentrations.

To do so, DOC concentrations, CDOM absorption and CDOM spectral properties $\left(S_{275-295}\right.$ and $\left.S_{R}\right)$, FDOM fluorescence, as well as chlorophyll $a(\operatorname{chl} a)$, and bacterial abundance were analyzed during the course of two mesocosm experiments, conducted as a part of the Collaborative Research Centre 754 (SFB754) "Climate-Biogeochemistry Interactions in the Tropical Ocean" (www.sfb754.de).

\section{Methods}

\subsection{Setup of the mesocosm experiments}

Two 8-day mesocosm experiments were conducted consecutively in October 2012 at the Instituto Nacional de Desenvolvimento das Pescas (INDP), Mindelo, Cape Verde. Seawater from $5 \mathrm{~m}$ depth was collected into four $600 \mathrm{~L}$ tanks on the night of the $1 / 2$ and 11/12 of October for the first and second experiment, respectively. The sampling was done with the RV Islândia south of São Vicente $\left(16^{\circ} 44.4^{\prime} \mathrm{N}\right.$, $25^{\circ} 09.4^{\prime} \mathrm{W}$ ). For each experiment, 16 mesocosm-bags were placed floating in 4 "flow-through" cooling baths that were kept at surface seawater temperature $\left(25.9-28.7^{\circ} \mathrm{C}\right)$ with the water from the Mindelo bay in front of the INDP. The mesocosms were filled alternately (about 10 s per filling event) and randomly from the tanks by gravity flow using submerged hose in order to achieve even distribution of the water and minimize bubble formation. A mesh to filter zooplankton was not used. The precise volume of each mesocosm was determined by the addition of $1.5 \mathrm{mmol}$ of silicate and subsequent measurement of the resulting silicate concentration. The water volume in the mesocosms ranged from 106 to $145 \mathrm{~L}$. For simulation of surface water conditions, the mesocosms were shaded with blue transparent lids to approximately $20 \%$ of sunlit irradiation $\left(56-420 \mu \mathrm{E} \mathrm{m}^{-2} \mathrm{~s}^{-1}\right.$, depending on cloud cover).

Nutrients were manipulated by adding different amounts of phosphate (DIP) and nitrate (DIN). In the first experiment, the DIP supply was varied ("Varied P") at relatively constant DIN concentrations in 12 of the 16 mesocosms, while in the second experiment initial DIN concentrations were varied ("Varied N") at the constant DIP supply in twelve of the sixteen mesocosms.

In addition to this, four "corner points", where both DIN and DIP were varied, were chosen to be repeated during both experiments (see target DIN and DIP values in Table 1). However, during the first experiment, setting the nutrient levels in one of the "corner point" mesocosms (mesocosm 10) was not successful and it was decided to adjust the DIN and DIP concentrations in this mesocosm to "Redfield N : $\mathrm{P}$ ratio" of 16 (Redfield, 1958) and therefore add another replicate to the treatment $12.00 \mathrm{~N} / 0.75 \mathrm{P}$. Another "corner point" mesocosm (mesocosm 5) during the first experiment was excluded from further analyses as no algal bloom had developed.

Initial sampling for biogeochemical parameters was accomplished immediately after the mesocosms filling (day 1). Nutrients were added after the initial sampling. Daily water sampling was conducted between 09:00 and 10:30 a.m. on days 2 to 8 .

The target and actual nutrient concentrations are shown in Table 1 and the corresponding treatment indications will be used in the following sections.

\subsection{Sampling and analyses}

\subsubsection{Particulate organic matter}

Samples of $500 \mathrm{~mL}$ for chl $a$ measurements were vacuumfiltered (<200 mbar) onto Whatman GF/F filters $(25 \mathrm{~mm}$, $0.7 \mu \mathrm{m}), 1 \mathrm{~mL}$ of ultrapure water was added and the filters were frozen at $-20^{\circ} \mathrm{C}$ for at least $24 \mathrm{~h}$. Subsequently, pigments were extracted using acetone and measured in a Trilogy ${ }^{\circledR}$ fluorometer (Turner Designs) calibrated with a chl $a$ standard (Anacystis nidulans, Walter CMP, Kiel, Germany) dilution series (Parsons et al., 1984). 
Table 1. Varied P and Varied N: target and measured concentrations of DIN and DIP and treatment identifications according to target values.

\begin{tabular}{lrrrr|rrrrrr}
\hline & \multicolumn{9}{c}{ Varied P } & \multicolumn{4}{c}{ Varied N } \\
\cline { 2 - 11 } Mesocosm ID & DIN & \multicolumn{1}{c}{ DIP } & DIN & DIP & Treatment & DIN & DIP & DIN & DIP & Treatment \\
\hline 1 & 12.00 & 0.75 & 11.52 & 0.73 & $12.00 \mathrm{~N} / 0.75 \mathrm{P}$ & 12.00 & 0.75 & 12.58 & 0.47 & $12.00 \mathrm{~N} / 0.75 \mathrm{P}$ \\
2 & 12.00 & 0.75 & 10.97 & 0.68 & $12.00 \mathrm{~N} / 0.75 \mathrm{P}$ & 12.00 & 0.75 & 12.36 & 0.51 & $12.00 \mathrm{~N} / 0.75 \mathrm{P}$ \\
3 & 12.00 & 0.75 & 10.63 & 0.52 & $12.00 \mathrm{~N} / 0.75 \mathrm{P}$ & 12.00 & 0.75 & 12.61 & 0.51 & $12.00 \mathrm{~N} / 0.75 \mathrm{P}$ \\
4 & 6.35 & 1.10 & 5.65 & 1.00 & $6.35 \mathrm{~N} / 1.10 \mathrm{P}$ & 6.35 & 0.40 & 6.91 & 0.18 & $6.35 \mathrm{~N} / 0.40 \mathrm{P}$ \\
5 & - & - & - & - & - & 17.65 & 1.10 & 18.43 & 0.79 & $17.65 \mathrm{~N} / 1.10 \mathrm{P}$ \\
6 & 12.00 & 1.25 & 10.74 & 1.14 & $12.00 \mathrm{~N} / 1.25 \mathrm{P}$ & 20.00 & 0.75 & 20.56 & 0.47 & $20.00 \mathrm{~N} / 0.75 \mathrm{P}$ \\
7 & 12.00 & 1.25 & 11.16 & 1.12 & $12.00 \mathrm{~N} / 1.25 \mathrm{P}$ & 20.00 & 0.75 & 20.60 & 0.45 & $20.00 \mathrm{~N} / 0.75 \mathrm{P}$ \\
8 & 12.00 & 1.25 & 10.89 & 1.09 & $12.00 \mathrm{~N} / 1.25 \mathrm{P}$ & 20.00 & 0.75 & 21.90 & 0.45 & $20.00 \mathrm{~N} / 0.75 \mathrm{P}$ \\
9 & 12.00 & 1.75 & 10.55 & 1.56 & $12.00 \mathrm{~N} / 1.75 \mathrm{P}$ & 4.00 & 0.75 & 4.62 & 0.44 & $4.00 \mathrm{~N} / 0.75 \mathrm{P}$ \\
10 & 12.00 & 0.75 & 10.82 & 0.61 & $12.00 \mathrm{~N} / 0.75 \mathrm{P}$ & 17.65 & 0.40 & 18.47 & 0.22 & $17.65 \mathrm{~N} / 0.40 \mathrm{P}$ \\
11 & 12.00 & 1.75 & 10.82 & 1.58 & $12.00 \mathrm{~N} / 1.75 \mathrm{P}$ & 4.00 & 0.75 & 4.49 & 0.47 & $4.00 \mathrm{~N} / 0.75 \mathrm{P}$ \\
12 & 12.00 & 1.75 & 11.07 & 1.53 & $12.00 \mathrm{~N} / 1.75 \mathrm{P}$ & 4.00 & 0.75 & 3.99 & 0.49 & $4.00 \mathrm{~N} / 0.75 \mathrm{P}$ \\
13 & 12.00 & 0.25 & 11.16 & 0.14 & $12.00 \mathrm{~N} / 0.25 \mathrm{P}$ & 2.00 & 0.75 & 2.06 & 0.46 & $2.00 \mathrm{~N} / 0.75 \mathrm{P}$ \\
14 & 12.00 & 0.25 & 11.18 & 0.16 & $12.00 \mathrm{~N} / 0.25 \mathrm{P}$ & 6.35 & 1.10 & 6.69 & 0.78 & $6.35 \mathrm{~N} / 1.10 \mathrm{P}$ \\
15 & 17.65 & 1.10 & 16.90 & 1.01 & $17.65 \mathrm{~N} / 1.10 \mathrm{P}$ & 2.00 & 0.75 & 1.87 & 0.56 & $2.00 \mathrm{~N} / 0.75 \mathrm{P}$ \\
16 & 12.00 & 0.25 & 11.33 & 0.15 & $12.00 \mathrm{~N} / 0.25 \mathrm{P}$ & 2.00 & 0.75 & 2.71 & 0.48 & $2.00 \mathrm{~N} / 0.75 \mathrm{P}$ \\
\hline
\end{tabular}

For bacterial cell counts, samples $(5 \mathrm{~mL})$ were fixed with $2 \%$ formaldehyde, frozen at $-80^{\circ} \mathrm{C}$ and transported to the home laboratory. Samples were diluted $1: 3$, stained with SYBR-Green and measured at a flow rate of $11.0 \mu \mathrm{L} \mathrm{min}-1$ by flow cytometry (FACScalibur, Becton Dickinson, San Jose, CA, USA).

\subsubsection{Dissolved organic matter}

DOC duplicate samples $(20 \mathrm{~mL})$ were filtered through combusted GF/F filters and collected in combusted glass ampoules. Samples were acidified with $80 \mu \mathrm{L}$ of $85 \%$ phosphoric acid, flame sealed and stored at $4{ }^{\circ} \mathrm{C}$ in the dark until analysis.

DOC samples were analyzed by applying the hightemperature catalytic oxidation method (TOC -VCSH, Shimadzu) adapted from Sugimura and Suzuki (1988). The instrument was calibrated every $8-10$ days by measuring six standard solutions of $0,500,1000,1500,2500$ and $5000 \mu \mathrm{gC} \mathrm{L}^{-1}$, prepared using a potassium hydrogen phthalate standard (Merck 109017). Every day before each set of measurements, ultrapure (MilliQ) water was used for setting the instrument baseline, followed by the measurement of the deep-sea water standard (Dennis Hansell, RSMAS, University of Miami) with known DOC concentration in order to verify result representation by the instrument. Additionally, two DOC control samples were prepared for each day of measurement using a potassium hydrogen phthalate standard (Merck 109017). The control samples had dissolved carbon concentrations within the range of those in samples and were measured along the sample analyses in order to avoid mistakes due to baseline flow during measurements. The DOC concentration was determined in each sample out of five to eight replicate injections.

For CDOM and FDOM, duplicate samples of $35 \mathrm{~mL}$ for each parameter were collected daily into combusted $\left(450{ }^{\circ} \mathrm{C}, 8 \mathrm{~h}\right)$ amber-glass vials after filtering through $0.45 \mu \mathrm{m}$ polyethersulfone syringe filters $\left(\mathrm{CHROMAPHIL}{ }^{\circledR}\right.$ Xtra PES-45/25, MACHEREY-NAGEL GmbH \& Co.KG). The samples were stored at $4{ }^{\circ} \mathrm{C}$ in the dark for 6 months pending analyses. All samples were brought to room temperature before analyses.

Absorption of CDOM was detected using a $100 \mathrm{~cm}$ path length liquid waveguide cell (LWCC-2100, World Precision Instruments, Sarasota, Florida) and a UV-VIS spectrophotometer (Ocean Optics USB 4000) in conjunction with the Ocean Optics DT-MINI-CS light source. The absorbance was measured against ultrapure water (MilliQ) by injection to the cell with a peristaltic pump. The measurements were done over a spectral range of 178.23 to $885.21 \mathrm{~nm}$ at $0.22 \mathrm{~nm}$ interval.

For the determination of FDOM, 3-D fluorescence spectroscopy - Excitation-Emission Matrix Spectroscopy (EEM) - was performed using a Cary Eclipse Fluorescence Spectrophotometer (Agilent Technologies) equipped with a xenon flash lamp. The fluorescence spectra for samples were measured in a 4 optical window $1 \mathrm{~cm}$ Quartz SUPRASIL ${ }^{\circledR}$ precision cell (Hellma ${ }^{\circledR}$ Analytics). The blank 3-D fluorescence spectra and Water Raman scans were performed daily using an Ultra-Pure Water Standard sealed cuvette (3/Q/10/WATER; Starna Scientific Ltd). The experimental wavelength range for sample and ultra-pure water scans was 230 to $455 \mathrm{~nm}$ in $5 \mathrm{~nm}$ intervals on excitation and 290 to $700 \mathrm{~nm}$ in $2 \mathrm{~nm}$ intervals on emission. Water Raman scans 
were recorded from 285 to $450 \mathrm{~nm}$ at $1 \mathrm{~nm}$ intervals for emission at the $275 \mathrm{~nm}$ excitation wavelength (Murphy et al., 2013). All fluorescence measurements were managed at $19^{\circ} \mathrm{C}$ (Cary Single Cell Peltier Assessory, VARIAN), PMT 900V, $0.2 \mathrm{~s}$ integration times and $5 \mathrm{~nm}$ slit width on excitation and emission monochromators. The absorbance for EEMs corrections was procured simultaneously with Shimadzu ${ }^{\circledR} 1800$ UV-VIS double-beam spectrophotometer. The absorbance was measured at the room temperature $\left(\sim 19^{\circ} \mathrm{C}\right)$ in 2 optical window $5 \mathrm{~cm}$ Quartz SUPRASIL ${ }^{\circledR}$ precision cell (Hellma ${ }^{\circledR}$ Analytics). The measurements were done at $1 \mathrm{~nm}$ wavelengths intervals from 230 to $750 \mathrm{~nm}$ against MilliQ water as a reference. The obtained data were converted to absorbance in a $1 \mathrm{~cm}$ cell.

\subsection{Data evaluation}

\subsubsection{CDOM}

The measured CDOM absorbance spectra were corrected to the refractive index of remaining particulate matter and colloids after Zhang et al. (2009) and for salinity after Nelson et al. (2007), and converted to absorption coefficients according to Bricaud et al. (1981):

$a_{\mathrm{CDOM}}(\lambda)=2.303 \times A(\lambda) / L ;$

where $a_{\mathrm{CDOM}}(\lambda)$ is the absorption coefficient at wavelength $\lambda\left(\mathrm{m}^{-1}\right), A(\lambda)$ is the absorbance value at same wavelength and $L$ is the effective optical path length (m).

In rivers and the coastal waters, absorption coefficients at $355\left(a_{\mathrm{CDOM}}(355)\right)$ and $375\left(a_{\mathrm{CDOM}}(375)\right) \mathrm{nm}$ are commonly used to express CDOM concentrations (Granskog et al., 2007; Stedmon et al., 2011). Absorption coefficients at 440-445 nm (e.g., $\left.a_{\mathrm{CDOM}}(440)\right)$ are used for comparison of field CDOM measurements to remote sensing (Swan et al., 2013). In open-ocean blue waters, absorbance at wavelengths of $400-600 \mathrm{~nm}$ is very low. Therefore, absorption at $325 \mathrm{~nm}$ $\left(a_{\mathrm{CDOM}}(325)\right)$ is often used for expression of the open-ocean CDOM concentrations (Nelson and Siegel, 2013). The area off Cape Verdean Archipelago, where water for mesocosms was taken, is not influenced by river inflow and is considered as the open-ocean area. Thus, $a_{\mathrm{CDOM}}(325)$ was chosen for expression of CDOM concentration.

Spectral slopes for the intervals $275-295 \mathrm{~nm}\left(S_{275-295}\right)$ and 350-400 $\left(S_{350-400}\right)$ were calculated after Helms et al. (2008) using log-transform linear regression.

The CDOM alteration indicator, $S_{\mathrm{R}}$, was also calculated after Helms et al. (2008) as a ratio of $S_{275-295}$ to $S_{350-400}$.

To describe changes in CDOM spectral properties along with changes in CDOM concentration, the following equation was used:

$S_{275-295}=\alpha+\beta / a_{\mathrm{CDOM}}(325) ;$

where $\alpha$ and $\beta$ are the regression coefficients.
The variability of the relationship $a_{\mathrm{CDOM}}(325) / \mathrm{DOC}$ vs. $S_{275-295}$ as a possible tool for DOC estimation from spectroscopic measurements, was expressed as

$a_{\mathrm{CDOM}}(325) / \mathrm{DOC}=e^{\left(\gamma-\delta S_{275-295)}\right.}+e^{\left(\varepsilon-\zeta S_{275-295)}\right.} ;$

where $\gamma, \delta, \varepsilon$ and $\zeta$ are regression coefficients.

\subsubsection{FDOM}

The 3-D fluorescence spectra were corrected for spectral bias, background signals and inner filter effects. Each EEM was normalized to the area of the ultra-pure water Raman peaks, measured in the same day. EEMs were combined into three-dimensional data array, analyzed by PARAFAC (Stedmon and Bro, 2008) and validated by split-half analysis using "drEEM toolbox for MATLAB" after Murphy et al. (2013).

Only up to three components could be validated. For models with more than three components the results varied during split-half analysis (see Murphy et al., 2013), indicating the possibility of identifying the instrument noise as a signal (e.g., Stedmon and Markager, 2005). The fluorescence of each component is stated as fluorescence at excitation and emission maximums in Raman units (RU).

\subsubsection{Mesocosm data treatment}

High variability of CDOM components (Fig. S1 in the Supplement) was observed on day 1 and day 2 of Varied $\mathrm{P}$ and day 1 of Varied N. This variability was likely associated to the filling and manipulation of the mesocosm bags and vanished afterwards. These days were excluded from further calculations, and day 3 and day 2 were defined as "start" or "beginning" of Varied P and Varied N, respectively. Day 8 was defined as the "end" of both experiments. To exclude initial variability, changes of the different DOM parameters over time were calculated as the difference between sampling day and start day:

$\Delta C i(k)=C i(k)-C i($ start $) ;$

where $C$ is a concentration, absorption or fluorescence intensity, $i$ is a mesocosm id $(i=1-16)$ and $k$ is the day of experiment.

For the presentation of the development over time, POM and DOM $\Delta$ values were averaged for each nutrient treatment.

The "corner points" are not presented in the DOM development plots, since both DIN and DIP in them were modified. Therefore, including these treatments could bias the interpretation of effects induced by single inorganic nutrients. However, in plots and analyses where DIP or DIN influence was investigated all treatments were included to avoid a single nutrient effect overestimation.

For an estimation of the drivers of changes in DOM optical properties, the covariance of total accumulation of DOM 
compounds $\left(\Delta_{8} \mathrm{DOM}\right)$ with the cumulative sum of POM $\left(\Sigma_{\mathrm{POM}}\right)$ parameters was tested by linear regression analysis.

Mean normalized deviations (mean dev. \%), calculated as

mean $\operatorname{dev} \%=\frac{100}{\overline{\Delta C} n} \sum_{\text {start }}^{\text {end }} \Delta C i(k)-\overline{\Delta C(k)}$;

where $C$ is a concentration, absorption or fluorescence intensity, $k$ is the day of experiment, $n$ is a total number of days $(n=$ end-start) and $i$ is a mesocosm ID $(i=1-16)$; $\Delta C i(k)$ is calculated by Eq. (4), $\overline{\Delta C(k)}$ is the mean $\Delta C$ for all mesocosms at the day $k$, and $\overline{\Delta C}$ is average $\Delta C$ for all mesocosms during the whole experiment. Mean dev. (\%) were tested against nutrient supply (Varied $\mathrm{P}$ and Varied $\mathrm{N}$ ) and DIN : DIP supply ratio in the mesocosms at day 2 in order to estimate the nutrient and stoichiometry effect on DOM accumulation in the mesocosms.

All statistical tests in this work were performed by the use of Sigma Plot 12.0 (Systat). The significance level was $p<0.05$.

\section{Results}

\subsection{Particulate organic matter development}

After nutrient addition, a phytoplankton bloom development was observed in all mesocosms during both experiments. Maximum chl $a$ concentrations in Varied $\mathrm{P}$ occurred at day 5 (Fig. 1a), with higher concentrations in treatments with initial nutrients supplied at lower or equal to Redfield $\mathrm{N}: \mathrm{P}$ ratio $(12.00 \mathrm{~N} / 0.75 \mathrm{P}, 12.00 \mathrm{~N} / 1.25 \mathrm{P}, 12.00 \mathrm{~N} / 1.75 \mathrm{P})$. However, no significant relationship of the cumulative sums of chl $a\left(\Sigma_{\operatorname{chl} a}\right)$ to DIP concentration was recognized ( $p>0.05$, $n=15$ ). In Varied N, chl $a$ concentrations reached its maximum at day 6 (Fig. 1b) and $\Sigma_{\operatorname{chl} a}$ were significantly affected by the initial DIN concentrations (Wilcoxon rank test: $p<0.001, n=16$ ), indicating that DIN was regulating phytoplankton biomass buildup.

Bacterial abundance increased until day 6 (paired $t$ test of day 1 and day 6 values: $p<0.001, n=15$ and $p<0.001$, $n=16$, respectively) in all mesocosms and then stayed relatively constant towards the end of both experiments (paired $t$ test of day 6 and end values: $p>0.05, n=15$, and $p>0.05$, $n=16$, respectively; Fig. 1c, d). In Varied P, cumulative sums of bacterial abundance $\left(\Sigma_{\text {bac }}\right)$ were not related to the initial DIP supply ( $p>0.05, n=15$ ). Highest bacterial abundance was observed at day 6 , yielding $2.0 \pm 0.7 \times 10^{6} \mathrm{~mL}^{-1}$ averaged for all treatments (Fig. 1c). In contrast, in Varied N, $\Sigma_{\text {bac }}$ was significantly positively correlated to DIN amendments $(p<0.01, n=16)$. The highest bacterial abundance of $2.6 \pm 0.2 \times 10^{6} \mathrm{~mL}^{-1}$ was observed at day 6 in the treatment with the highest initial DIN concentration (20.00N/0.75P).

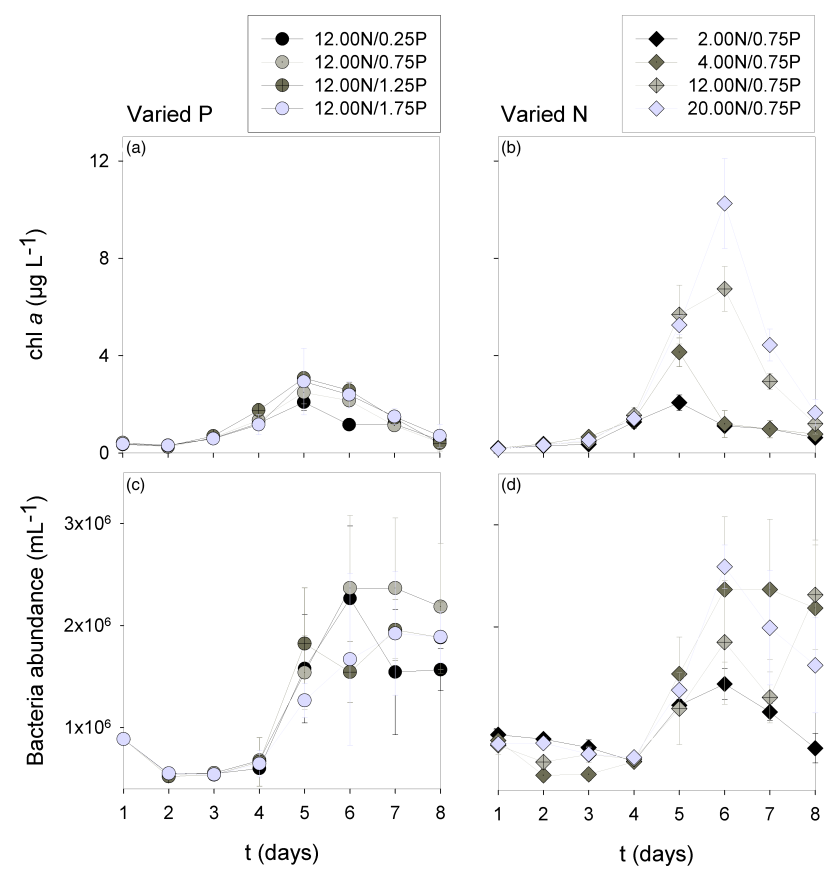

Figure 1. Mean development of chl $a$ (a), bacterial abundance (c) in replicated treatments during Varied $\mathrm{P}$; and chl $a(\mathbf{b})$, bacterial abundance (d) in replicated treatments during Varied $\mathrm{N}$.

\subsection{Dissolved organic matter}

\subsubsection{Dissolved organic matter concentration}

The initial DOC concentration (day 3), did not differ significantly between treatments in Varied $\mathrm{P}$ (one way ANOVA: $p>0.05, n=15)$ and was $99 \pm 5 \mu \mathrm{mol} \mathrm{L}^{-1}$ on average. In contrast, in Varied $\mathrm{N}$ initial DOC concentrations (day 2) varied significantly among treatments (HolmSidak test: $p<0.001, n=16$ ) with $87 \pm 2 \mu \mathrm{mol} \mathrm{L}^{-1}$ in the treatment with second lowest initial DIN concentrations (4.00N/0.75P), $91 \pm 1 \mu \mathrm{mol} \mathrm{L}^{-1}$ on average for the Redfield DIN : DIP treatment $(12.00 \mathrm{~N} / 0.75 \mathrm{P})$ and for the treatment with the lowest initial DIN concentrations $(2.00 \mathrm{~N} / 0.75 \mathrm{P})$, and $95 \pm 3 \mu \mathrm{mol} \mathrm{L}^{-1}$ in the treatment with the highest initial DIN concentrations (20.00N/0.75P). The calculation of DOC accumulation $(\triangle \mathrm{DOC})$ thus allowed a better comparison of bulk DOC dynamics between treatments than absolute concentrations and will be given in the following.

During both experiments, DOC accumulated significantly over time (paired $t$ test of start and end values: $p<0.001$, $n=15$ and 16, respectively) with generally higher accumulation observed in Varied $\mathrm{N}$ than in Varied P (Mann-Whitney rank sum test: $p<0.001, n=120)$. On day 8 , accumulation of DOC $\left(\Delta_{8}\right.$ DOC $)$ was highest $\left(33 \pm 23 \mu \mathrm{mol} \mathrm{L}^{-1}\right)$ in the highest DIP treatment (12.00N/1.75P) in Varied P (Fig. 2a), as well as in the highest DIN treatment $(20.00 \mathrm{~N} / 0.75 \mathrm{P})$ in Varied N $\left(67 \pm 3 \mu \mathrm{mol} \mathrm{L}^{-1}\right.$; Fig. $\left.2 b\right)$. 
Initial average $\mathrm{CDOM}$ absorption at $325 \mathrm{~nm}\left(a_{\mathrm{CDOM}}(325)\right)$ was $0.17 \pm 0.03 \mathrm{~m}^{-1}$ and $0.15 \pm 0.01 \mathrm{~m}^{-1}$ for mesocosms of Varied P and Varied N, respectively (Fig. S1c, d). For both experiments, the starting CDOM absorption values were not significantly different between treatments (one way ANOVA: $p>0.05, n=15$ and $p>0.05, n=16)$. However, they differed between the two experiments (one way ANOVA: $p<0.05, n=31)$. CDOM accumulation $\left(\Delta a_{\mathrm{CDOM}}(325)\right)$ will be given in the following, as it allows a better comparison of CDOM dynamics between experiments than absolute absorption coefficients.

CDOM accumulated over time during both experiments (paired $t$ test of start and end values: $p<0.001, n=15$ and $p<0.001, n=16$, respectively). CDOM accumulation on day $8\left(\Delta_{8} a_{\mathrm{CDOM}}(325)\right)$ was highest in the medium-to-high DIP treatment (12.00N/0.75P, $12.00 \mathrm{~N} / 1.25 \mathrm{P}, 12.00 \mathrm{~N} / 1.75 \mathrm{P})$ in Varied $\mathrm{P}\left(0.35 \pm 0.03 \mathrm{~m}^{-1}\right.$; Fig. $\left.2 \mathrm{c}\right)$ and in the highest DIN treatment $(20.00 \mathrm{~N} / 0.75 \mathrm{P})$ in Varied $\mathrm{N}\left(0.48 \pm 0.13 \mathrm{~m}^{-1}\right.$; Fig. 2d).

Spectral slopes, calculated within the $275-295 \mathrm{~nm}$ spectral range, $\left(S_{275-295}\right)$ differed between treatments in the beginning of Varied N (one way ANOVA: $p<0.05, n=16$ ), whereas treatments in the beginning of Varied $\mathrm{P}$ were not significantly different (one way ANOVA: $p>0.05, n=15$ ). In order to avoid the influence of initial differences of spectral slopes on data analyses, daily changes in spectral slopes $\left(\Delta S_{275-295}\right)$ were calculated. More negative $\Delta S_{275-295}$ indicate that the spectral slope is decreasing. As the spectral slope decreased, CDOM absorption at longer wavelengths became higher, indicating accumulation of HMW CDOM.

$S_{275-295}$ decreased over time in both experiments (paired $t$ test of start and end values: $p<0.01, n=15$ and $p<0.01, n=16$, for Varied $\mathrm{P}$ and Varied $\mathrm{N}$ respectively). The most negative $\Delta S_{275-295}$ values $(-0.016 \pm 0.004$ and $-0.014 \pm 0.002 \mathrm{~nm}^{-1}$ ) were observed in the treatments with medium and high initial DIP concentrations $(12.00 \mathrm{~N} / 0.75 \mathrm{P}$, $12.00 \mathrm{~N} / 1.25 \mathrm{P}, 12.00 \mathrm{~N} / 1.75 \mathrm{P}$ ) at the end (day 8 ) of Varied $\mathrm{P}$ (Fig. 2e) and in the treatment with the highest initial DIN concentrations (20.00N/0.75P) at the end (day 8) of Varied N (Fig. 2f), respectively. In general, $\Delta S_{275-295}$ decreased faster in treatments with medium and high initial DIP concentrations $(12.00 \mathrm{~N} / 0.75 \mathrm{P}, 12.00 \mathrm{~N} / 1.25 \mathrm{P}, 12.00 \mathrm{~N} / 1.75 \mathrm{P})$ in Varied $\mathrm{P}$ and in treatment with the highest initial DIN concentrations (20.00N/0.75P) in Varied N (Table 2).

In the relationship between $S_{275-295}$ and $a_{\mathrm{CDOM}}(325)$ no apparent differences between treatments were found. The relationship could be explained by Eq. (2) with $\alpha=0.022$ and $\delta=0.0035$ (Fig. 3).

The $S_{\mathrm{R}}$ had much larger uncertainties within treatments than spectral slopes themselves. The initial $S_{\mathrm{R}}$ (day 3 and day 2) was not statistically different among treatments in each experiment (one way ANOVA: $p>0.05, n=15$ and 16, respectively) and between experiments (one way ANOVA: $p>0.05, n=31$ ).
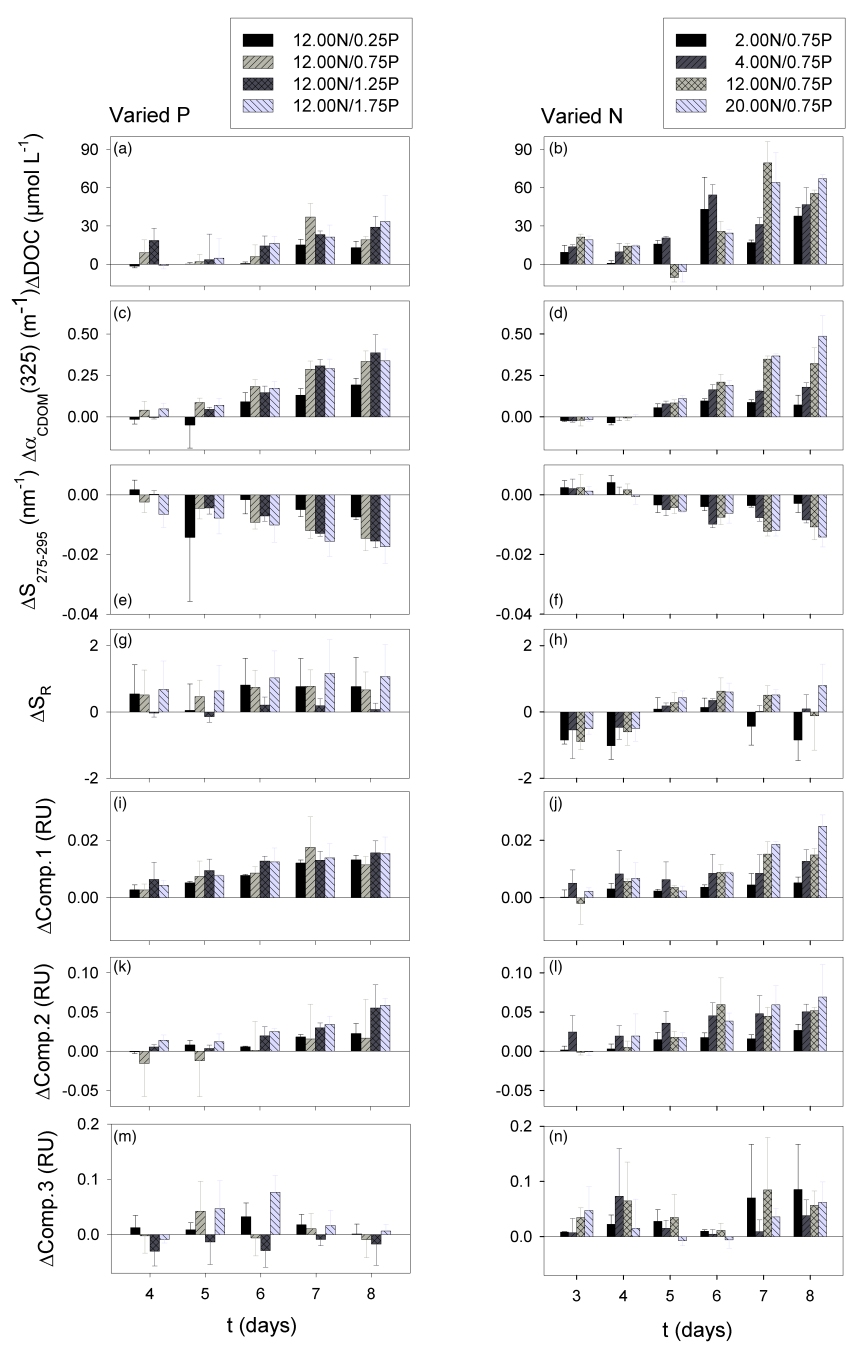

Figure 2. Accumulation over time: of DOC $(\triangle \mathrm{DOC})$ (a) during the Varied P and (b) Varied N; of CDOM $\left(\Delta a_{\mathrm{CDOM}}(325)\right)$ (c) during the Varied $\mathrm{P}$ and (d) Varied N; of Spectral Slope $\left(\Delta S_{275-295}\right)$ (e) during the Varied $\mathrm{P}$ and (f) Varied $\mathrm{N}$; of spectral slope ratio $\left(\Delta S_{\mathrm{R}}\right)$ (g) during the Varied $\mathrm{P}$ and (h) Varied $\mathrm{N}$; of first FDOM component fluorescence intensity ( $\Delta$ Comp. 1 ) (i) during the Varied $\mathrm{P}$ and (j) Varied N; of second FDOM component fluorescence intensity ( $\triangle$ Comp.2) (k) during the Varied $\mathrm{P}$ and (l) Varied $\mathrm{N}$; of third FDOM component fluorescence intensity $(\Delta$ Comp.3) (m) during the Varied P and (n) Varied N.

$S_{\mathrm{R}}$ increased only slightly over time in almost all mesocosms of Varied P (paired $t$ test of start and end values: $p<0.05, n=15$; Fig. $2 \mathrm{~g}$ ). In Varied $\mathrm{N}, S_{\mathrm{R}}$ increased significantly on day 5 (paired $t$ test of start and day 5 values: $p<0.001, n=16)$ and decreased again slightly on day 7 (paired $t$ test of day 5 and day 7 values: $p<0.05, n=16$ ) in almost all mesocosms (Fig. 2h).

Three FDOM components with distinct spectral properties were identified during PARAFAC analysis of our data set. The first FDOM component (Comp.1) was excited at 
Table 2. Estimated linear change (per day) of spectral slope parameter $\left(\mathrm{d} S_{275-295}\right)$ for replicated treatments.

\begin{tabular}{|c|c|c|c|c|c|c|c|c|}
\hline \multirow[t]{2}{*}{ Parameter } & \multicolumn{4}{|c|}{ Varied P } & \multicolumn{4}{|c|}{ Varied N } \\
\hline & $12.00 \mathrm{~N} / 0.25 \mathrm{P}$ & $12.00 \mathrm{~N} / 0.75 \mathrm{P}$ & $12.00 \mathrm{~N} / 1.25 \mathrm{P}$ & $12.00 \mathrm{~N} / 1.75 \mathrm{P}$ & $2.00 \mathrm{~N} / 0.75 \mathrm{P}$ & $4.00 \mathrm{~N} / 0.75 \mathrm{P}$ & $12.00 \mathrm{~N} / 0.75 \mathrm{P}$ & $20.00 \mathrm{~N} / 0.75 \mathrm{P}$ \\
\hline $\begin{array}{l}\mathrm{d} S_{275-295} \\
\left(\mathrm{~nm}^{-1} \mathrm{~d}^{-1}\right)\end{array}$ & $-2.3 \times 10^{-3}$ & $-3.2 \times 10^{-3}$ & $-4.0 \times 10^{-3}$ & $-3.0 \times 10^{-3}$ & $-1.4 \times 10^{-3}$ & $-2.3 \times 10^{-3}$ & $-3.2 \times 10^{-3}$ & $-3.3 \times 10^{-3}$ \\
\hline
\end{tabular}

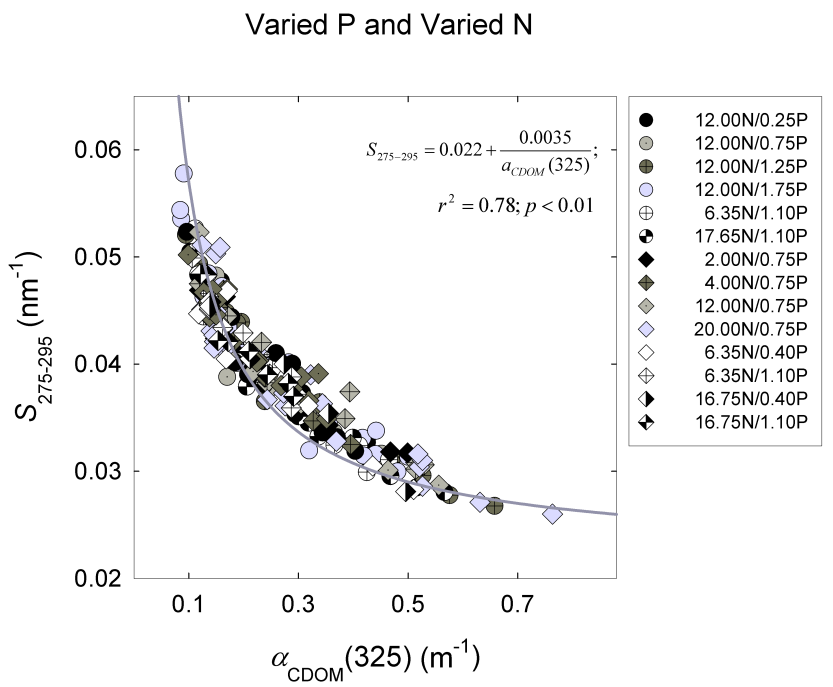

Figure 3. Spectral slope $S_{275-295}$ against $\operatorname{CDOM}\left(a_{\mathrm{CDOM}}(325)\right)$ obtained during both, Varied $\mathrm{P}$ and Varied $\mathrm{N}$ experiments (symbols). The dark-gray line is the best fit to the data.

$235 \mathrm{~nm}$ and emitted at $440-460 \mathrm{~nm}$, the second (Comp.2) and the third (Comp.3) FDOM components were excited at 275 and $265 \mathrm{~nm}$ and emitted at 340 and $294 \mathrm{~nm}$ respectively. Both also had secondary excitation peaks at wavelengths less than $230 \mathrm{~nm}$ (Table 3, Fig. 4).

The initial fluorescence of Comp. 1 was $0.019 \pm 0.001 \mathrm{Ra}-$ man Units (RU) in Varied P and $0.0108 \pm 0.0009$ RU in Varied N. Initially, Comp.1 fluorescence was not significantly different between treatments in both Varied $\mathrm{P}$ and Varied $\mathrm{N}$ (one way ANOVA: $p>0.05, n=15$ and $p>0.05, n=16$, respectively) in contrast to initial differences between two experiments (one way ANOVA: $p<0.01, n=31$ ).

Subtracting the initial fluorescence of Comp.1 ( $\Delta$ Comp.1) allowed tracing the accumulation of freshly produced Comp. 1 during the experiments (Fig. 2i, j).

$\Delta$ Comp. 1 indicated an accumulation of Comp. 1 over time in both experiments (paired $t$ test of start and end values: $p<0.001, n=15$ and $p<0.001, n=16$ ). In Varied P, differences in $\Delta$ Comp. 1 fluorescence between treatments at the end of the experiment were not significant ( $t$ test: $p>0.05$, $n=6$ ) and revealed $0.014 \pm 0.004 \mathrm{RU}$ on the average for all mesocosms (Fig. 2i). In Varied $\mathrm{N}$, the highest $\Delta$ Comp. 1 fluorescence intensities of $0.025 \pm 0.004 \mathrm{RU}$ were found in the treatment with the highest DIN supply $(20.00 \mathrm{~N} / 0.75 \mathrm{P}$;

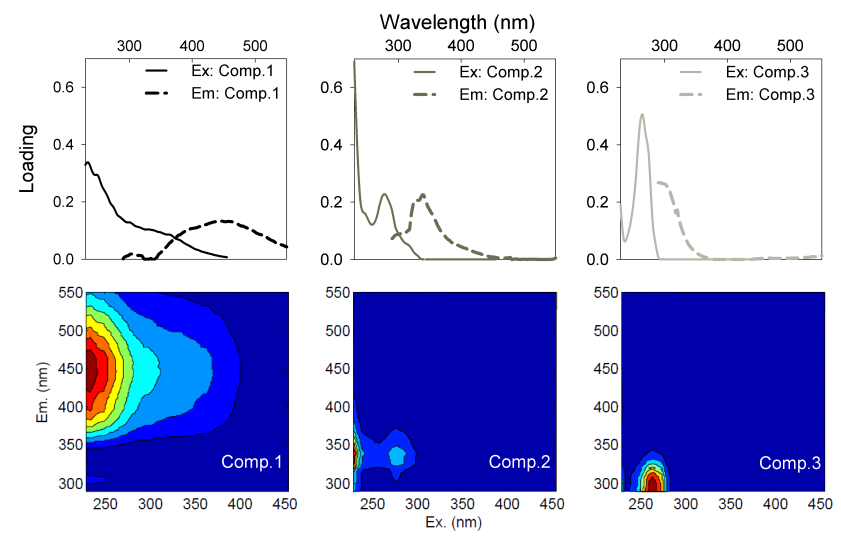

Figure 4. Spectral loadings (upper panels) and fingerprints (lower panels) of the FDOM components.

Fig. 2j). Here, clear differences were observed between treatments at the end of the experiment (one way ANOVA: $p<0.01, n=8$ ).

The fluorescence intensities of Comp. 2 were almost identical at the start of Varied $\mathrm{P}$ and Varied $\mathrm{N}$, yielding $0.029 \pm 0.005 \mathrm{RU}$ and $0.029 \pm 0.007 \mathrm{RU}$, respectively. No significant differences were observed between treatments (one way ANOVA: $p>0.05, n=15$ and $p>0.05, n=16$, for Varied $\mathrm{P}$ and Varied $\mathrm{N}$ respectively) and experiments (one way ANOVA: $p>0.05, n=31$ ).

Comp. 2 fluorescence increased in all mesocosms over time (paired $t$ test of start and end values: $p<0.001$, $n=15$ and $p<0.001, n=16$; Fig. $2 \mathrm{k}, 1$ ). At the end (day 8) of Varied P, the maximum $\Delta$ Comp.2 fluorescence was $0.063 \pm 0.007 \mathrm{RU}$ in the treatment with highest DIP addition (12.00N/1.75P; Fig. 2k). At day 8, it was significantly higher than that in the treatment with the lowest initial DIP concentration (12.00N/0.25P; $t$ test: $p<0.05, n=6)$. Differences between treatments with the highest $(20.00 \mathrm{~N} / 0.75 \mathrm{P})$ and the lowest $(2.00 \mathrm{~N} / 0.75 \mathrm{P})$ initial DIN concentrations at the end (day 8) of Varied $\mathrm{N}$ were not significant ( $t$ test: $p>0.05$, $n=6)$ and the maximum $\Delta$ Comp. 2 fluorescence comprised $0.04 \pm 0.03 \mathrm{RU}$ on average for all mesocosms (Fig. 21).

The Comp. 3 fluorescence intensity was highly variable during both experiments (Fig. $2 \mathrm{~m}$, n). Its starting values were not statistically different between Varied P and Varied N (two way ANOVA: $p>0.05, n=31$ ) and comprised $0.03 \pm 0.02$ RU in both. 
Table 3. Spectral characteristics of excitation and emission maxima and range of intensities of the three fluorescent components identified by PARAFAC modeling in this study and their comparison with previously reported ones.

\begin{tabular}{|c|c|c|c|c|c|c|}
\hline \multicolumn{4}{|c|}{ this study } & \multicolumn{3}{|c|}{ Literature } \\
\hline Peak & $\begin{array}{r}\text { Excitation } \\
\max \end{array}$ & $\begin{array}{r}\text { Emission } \\
\max \end{array}$ & $\begin{array}{r}\text { Intensity range } \\
\text { (RU) }\end{array}$ & Peak (Ex/Em) & Reference & Properties \\
\hline Comp.1 & 235 & $440-460(300)$ & $0.0090-0.0450$ & $\begin{array}{l}1(<240(355) / 476) \\
\text { A }(230-260 / 380-460) \\
\text { C3 }(250(310) / 400) \\
\text { C3 }(255(330) / 412) \\
1(<230-260 / 400-500)\end{array}$ & $\begin{array}{l}\text { Stedmon and Markager (2005) } \\
\text { Coble (1996) } \\
\text { Kowalczuk et al. (2009) } \\
\text { Zhang et al. (2009) } \\
\text { Ishii et al. (2012) }\end{array}$ & $\begin{array}{l}\text { Humic-like; Accumulated in P- and Si- limited bags } \\
\text { Source: Microbial degradation, Sink: Photodegradation } \\
\text { humic-, fulvik-like; Sourse: autochtonous, al- } \\
\text { lochthonous; terrestrial } \\
\text { Source: Bacterial reworking } \\
\text { Terrestrial and marine humic-like; Source: microbial ac- } \\
\text { tivity } \\
\text { Small-sized molecules, Photo-resistant, biologically } \\
\text { unavailable, conservative tracer; Source: Photodegrada- } \\
\text { tion }\end{array}$ \\
\hline Comp.2 & $<230(275)$ & 340 & $0.0200-0.1305$ & $\begin{array}{l}6(280 / 338) \\
\mathrm{T}(275 / 340) \\
\text { peak-T }(275 / 358)\end{array}$ & $\begin{array}{l}\text { Stedmon and Markager (2005) } \\
\text { Coble (2007) } \\
\text { Romera-Castillo et al. (2010) }\end{array}$ & $\begin{array}{l}\text { Protein-like; } \\
\text { Tryptophan-like fluorescence of proteinaceous material } \\
\text { Source: algae at the growth; Sink: UV, microbial rework- } \\
\text { ing } \\
\text { Tryptophan-like, protein-like; autochtonous } \\
\text { protein-like; Source: sterile algae }\end{array}$ \\
\hline Comp. 3 & 265 & $290-300$ & $0.0004-0.2105$ & $\begin{array}{l}\text { B }(275 / 305) \\
\text { C2 }(275 /<300) \\
7(270 / 299)\end{array}$ & $\begin{array}{l}\text { Coble (2007) } \\
\text { Zhang et al. (2009) } \\
\text { Yamashita et al. (2008) }\end{array}$ & $\begin{array}{l}\text { Protein-like: fluorescence of tryptophan and tyrosine in } \\
\text { peptides } \\
\text { Higher production rates during establishing algal bloom } \\
\text { Source: growing algae Sink: aggregation or microbial } \\
\text { uptake } \\
\text { Tyrosine-like, protein-like; Source: autochtonous } \\
\text { Tyrosine-like, protein-like; Source: autochtonous } \\
\text { Tyrosine-like, protein-like; Source: autochtonous }\end{array}$ \\
\hline
\end{tabular}

In Varied P, Comp.3 fluorescence intensity increased from the start until day 5 (paired $t$ test of start and day 5 values: $p<0.05, n=15$ ) and decreased after day 6 until the end of the experiment (paired $t$ test of day 5 and end values: $p<0.05, n=15$; Fig. $2 \mathrm{~m}$ ). In Varied N, Comp. 3 accumulated significantly only after day 6 (paired $t$ test of day 6 and end values: $p<0.05, n=16$; Fig. 2 n).

\subsubsection{Assessing the origin of optically active dissolved organic matter}

To investigate a potential influence of phytoplankton or bacteria abundances on DOC concentrations and CDOM and FDOM accumulation, cumulative sums of $\operatorname{chl} a\left(\Sigma_{\operatorname{chl} a}\right)$ and bacterial abundance $\left(\Sigma_{\text {bac }}\right)$ of each mesocosm (Table S2 in the Supplement) were tested against total accumulation of DOM components at day $8\left(\Delta_{8} \mathrm{DOM}\right)$ using linear regression analysis.

Values of $\Delta_{8}$ DOC correlated significantly with $\Sigma_{\text {chl } a}$ in Varied $\mathrm{P}(p<0.05, n=15)$ and in Varied $\mathrm{N}(p<0.001$, $n=16)$, but not with $\Sigma_{\text {bac }}(p>0.05, n=15$ and $p>0.05$, $n=16$, respectively).

CDOM accumulation $\left(\Delta_{8} a_{\mathrm{CDOM}}(325)\right)$ correlated significantly to $\Sigma_{\text {chl } a}$ in Varied P ( $\left.p<0.05, n=15\right)$ and Varied N ( $p<0.001, n=16$ ), indicating that phytoplankton biomass was regulating CDOM dynamics in both experiments. While no covariance of $\Delta_{8} a_{\mathrm{CDOM}}(325)$ with $\Sigma_{\mathrm{bac}}$ was observed during Varied $\mathrm{P}(p>0.05, n=15)$, a significant correlation of $\Delta_{8} a_{\mathrm{CDOM}}(325)$ with $\Sigma_{\mathrm{bac}}(p<0.05, n=16)$ occurred in
Varied N, indicating that bacteria may be partially responsible for CDOM dynamics under DIN stimulation.

$\Delta$ Comp. 1 behaved similarly to $\Delta_{8} a_{\mathrm{CDOM}}(325)$ during both experiments. However, $\Delta_{8}$ Comp. 1 was neither correlated to $\Sigma_{\text {bac }}(p>0.05, n=15)$, nor to $\Sigma_{\text {chl } a}(p>0.05$, $n=15)$ in Varied P. In contrast, $\Delta_{8}$ Comp. 1 was significantly correlated to both $\Sigma_{\mathrm{chl} a}(p<0.001, n=16)$ and $\Sigma_{\text {bac }}$ ( $p<0.05, n=16)$ in Varied $\mathrm{N}$.

Similar to $\Delta_{8}$ Comp. 1 , in Varied P, $\Delta_{8}$ Comp. 2 did not reveal a significant relationship to $\Sigma_{\operatorname{chl} a}(p>0.05, n=15)$ or to $\Sigma_{\text {bac }}(p>0.05, n=15)$. In Varied N, $\Delta_{8}$ Comp. 2 also did not correlate to $\Sigma_{\mathrm{chl} a}(p>0.05, n=16)$, but it correlated significantly to $\Sigma_{\text {bac }}(p<0.01, n=16)$, supporting a potential influence of bacterial abundance on fluorescence intensities of Comp. 2.

In contrast to $\Delta_{8}$ Comp. 1 and $\Delta_{8}$ Comp. $2, \Delta_{8}$ Comp. 3 did not covariate, neither with $\Sigma_{\text {bac }}(p>0.05, n=15$ and $p>0.05, n=16)$, nor with $\Sigma_{\text {chl } a}(p>0.05, n=15$ and $p>0.05, n=16)$ in both experiments.

\subsubsection{Effect of inorganic nutrients on optically active DOM}

To assess the nutrient influence on DOM accumulation, mean normalized deviations (mean dev. $\%$ ) of $\triangle \mathrm{DOC}, \triangle \mathrm{CDOM}$ $\left(\Delta a_{\mathrm{CDOM}}(325)\right)$ and $\triangle \mathrm{FDOM}$ were calculated for each mesocosm (including "corner" points) and tested against initial DIP supply in Varied P, and against initial DIN supply in Varied N using linear regression analysis (Fig. 5), and also against DIN : DIP ratio combining both experiments. 


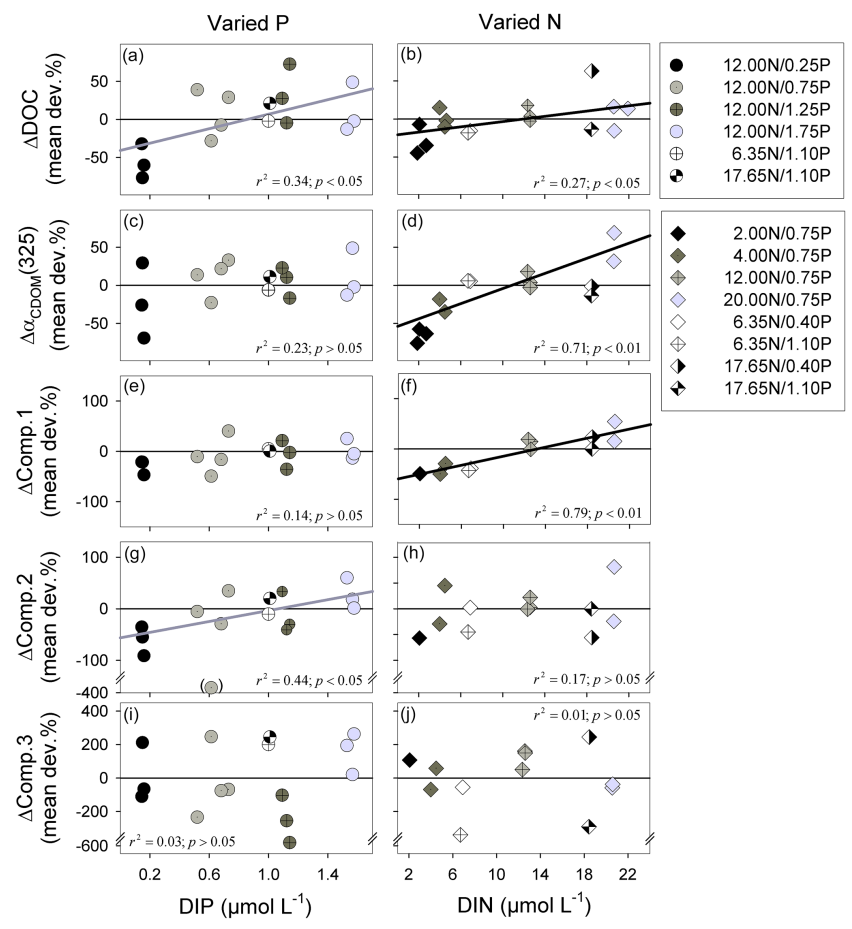

Figure 5. Mean normalized deviations of DOM accumulation against initial nutrients supply. The $\triangle \mathrm{DOC}$ against DIP initial supply in Varied P (a) and against DIN initial supply in Varied N (b), the CDOM absorption $\left(\Delta a_{\mathrm{CDOM}}(325)\right)$ against DIP initial supply in Varied $P$ (c) and against DIN initial supply in Varied $N(\mathbf{d})$, the first FDOM component intensity ( $\Delta$ Comp.1) against DIP initial supply in Varied P (e) and against DIN initial supply in Varied $\mathrm{N}$ (f), the second FDOM component intensity ( $\Delta$ Comp.2) against DIP initial supply in Varied P (g) and against DIN initial supply in Varied N (h) and the third FDOM component intensity ( $\Delta$ Comp.3) against DIP initial supply in Varied P (i) and against DIN initial supply in Varied N (j) are shown as dashed symbols. The linear regressions are shown by thick light-gray lines in Varied $\mathrm{P}$ and by thick black lines in Varied $\mathrm{N}$ for those DOM parameters, where covariance with initial nutrients supply was significant. The symbol in brackets in (g) was considered as an outlier and excluded from linear regression analysis.

DOC accumulation was related to the initial inorganic nutrient supply in both experiments. Higher $\triangle \mathrm{DOC}$ (mean dev. $\%)$ corresponded to higher DIP supply ( $p<0.05, n=15)$ in Varied P (Fig. 5a) and to higher DIN supply ( $p<0.05$, $n=16$ ) in Varied N (Fig. 5b). However, no overall effect of DIN : DIP ratios was revealed when data from both experiments were combined ( $p>0.05, n=31)$. Therefore, accumulation of DOC, in general, was dependent rather on total initial amount of macronutrients, than on the relative concentration of DIN to DIP.

$\triangle \mathrm{CDOM}$ (mean dev. \%) correlated significantly to DIN supply ( $p<0.001, n=14$; Fig. $4 \mathrm{c}$ ), but not to DIP supply ( $p>0.05, n=15$; Fig. $5 \mathrm{~d}$ ). Similar to $\triangle \mathrm{DOC}$ (mean dev. \%), no effect of initial DIN : DIP ratios on $\triangle$ CDOM (mean dev. $\%$ ) was determined ( $p>0.05, n=31$ ).

$\Delta$ Comp.1 (mean dev. \%) did not exhibit a significant relationship to the initial DIP supply ( $p>0.05, n=15$; Fig. 5e), but correlated significantly to the initial DIN concentrations ( $p<0.001, n=12$; Fig. 5f).

In contrast, $\Delta$ Comp. 2 (mean dev. \%) increased with an increase of the initial DIP supply ( $p<0.05, n=14$; Fig. $5 \mathrm{~g}$ ), but not of the initial DIN supply ( $p>0.05, n=12$; Fig. 5h). Thus, Comp. 2 accumulation was higher under the higher DIP concentrations.

In contrast to both previous FDOM components, $\Delta$ Comp.3 (mean dev. \%) did not reveal covariance to DIP ( $p>0.05, n=15$; Fig. 5i), nor to DIN $(p>0.05, n=12)$ initial supply (Fig. 5n).

No overall effect of DIN:DIP ratios on $\Delta$ Comp.1, $\Delta$ Comp.2 and $\Delta$ Comp.3 (mean dev. $\%$ ) was determined when data from both experiments were combined $(p>0.05$, $n=27, p>0.05, n=27$ and $p>0.05, n=27$, respectively).

Hence, accumulation of Comp.1 was dependent on the initial DIN concentrations, accumulation of Comp. 2 increased with an increase of initial DIP concentrations and Comp. 3 was unaffected by nutrient treatments.

\subsubsection{Nutrients effects on the relationship between CDOM and DOC}

To investigate the relationship between CDOM absorption and DOC concentrations during the course of the experiments, daily DOM accumulation $(\triangle \mathrm{DOC})$ was tested against daily accumulation of CDOM at $325 \mathrm{~nm}\left(\Delta a_{\mathrm{CDOM}}(325)\right)$ by linear regression analysis for each mesocosm and for all data combined (Fig. 6a, b). Direct overall relationships were observed between $\triangle \mathrm{DOC}$ and $\Delta a_{\mathrm{CDOM}}(325)$ in both, Varied $\mathrm{P}$ $(p<0.001, n=75)$ and Varied $\mathrm{N}(p<0.001, n=95)$.

The estimated slopes of linear regressions, determined for each mesocosm for $\Delta a_{\mathrm{CDOM}}(325)$ vs. $\triangle \mathrm{DOC}$ $\left(\mathrm{d} \Delta a_{\mathrm{CDOM}}(325) / \mathrm{d} \Delta \mathrm{DOC}\right)$, were tested for correlation with the initial DIP (Fig. 6c) and DIN (Fig. 6d) concentrations, in Varied $\mathrm{P}$ and Varied $\mathrm{N}$, respectively. The $\mathrm{d} \Delta a_{\mathrm{CDOM}}(325) / \mathrm{d} \Delta \mathrm{DOC}$ significantly increased with an increase of initial DIN supply ( $p<0.01, n=16$ ), indicating that the colored fraction of DOC was affected by nutrient availability, specifically by DIN supply.

Although the relationship between CDOM and DOC revealed a dependency on initial DIN supply, the values of $a_{\mathrm{CDOM}}(325)$ to DOC ratio $\left(a_{\mathrm{CDOM}}(325) / \mathrm{DOC}\right)$ did not reveal a significant nutrient effect, when plotted against $S_{275-295}$ (Fig. 6e).

All data of $S_{275-295}$ and $a_{\mathrm{CDOM}}(325)$ / DOC of our study could be described by Eq. (3), with coefficients $\gamma, \delta, \varepsilon$ and $\zeta$ equal to $5.67,81.23,3.18$ and 23.03, respectively (Fig. 6e). 

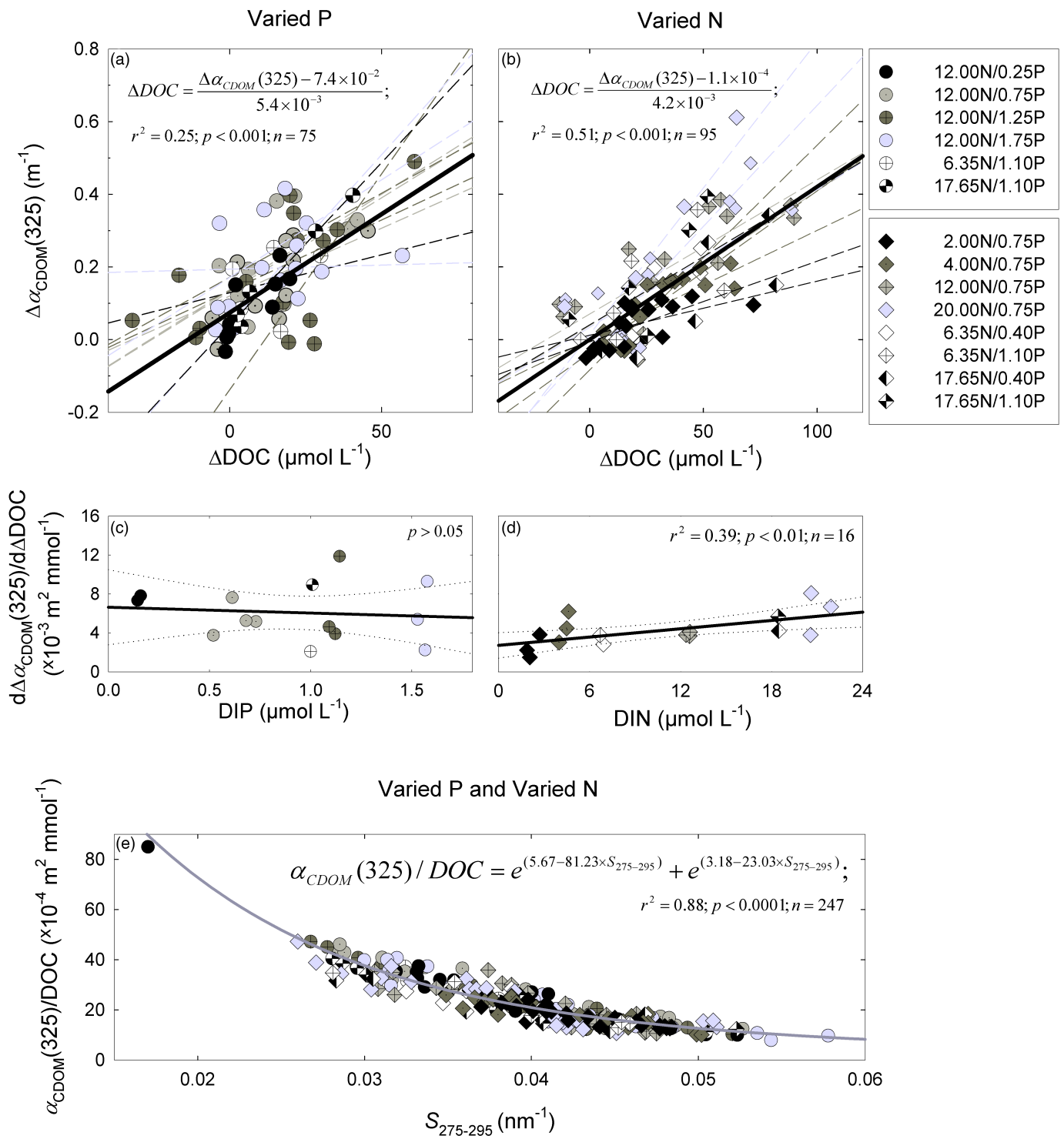

Figure 6. Regression plots of $\triangle \mathrm{DOC}$ against $\Delta a_{\mathrm{CDOM}}(325)$ (a) during Varied $\mathrm{P}$ (shaded circles) and (b) during Varied $\mathrm{N}$ (shaded diamonds). The regression lines for each mesocosm are shown in dashed lines; thick black lines are regressions for all data from Varied $\mathrm{P}$ and Varied $\mathrm{N}$ respectively. The estimated slopes of regressions for each mesocosm from $(\mathbf{a}, \mathbf{b})$ are plotted as shaded circles for Varied $\mathrm{P}(\mathbf{c})$ and shaded diamonds for Varied N (d). The thick black line is the linear regression line with $95 \%$ confidence interval (thin dotted lines). The estimated slopes covariance in Varied $\mathrm{N}$ to DIN initial supply can be expressed as $d \Delta a_{\mathrm{CDOM}}(325) / d \Delta \mathrm{DOC}=2.7 \times 10^{-3}+0.14 \times 10^{-3} \mathrm{DIN}(\mathbf{d})$. Spectral slopes $S_{275-295}$ against $a_{\mathrm{CDOM}}(325)$ /DOC for all mesocosms from both experiments are shown as shaded symbols (e). The dark-gray line is the best fit to the data obtained in this study.

\section{Discussion}

\subsection{Nutrient effects on the production and cycling of optically active DOM}

Our results indicate that chl $a$ accumulation and bacterial growth were stimulated by DIN supply. Along with the response of POM production to inorganic nutrient amendments, changes in the optically active DOM fractions were observed.
Initial DOC concentrations, measured in both experiments (Fig. S1a, b), were in the range or slightly higher than those previously reported and modeled for the upper $30 \mathrm{~m}$ of the Tropical Atlantic Ocean watercolumn (Hansell et al., 2009).

In both experiments, DOC accumulated over time (Fig. 2a, b) and seemed to be produced mainly through phytoplankton release. The highest DOC accumulation was observed in the moment of rapid transition from nutrient-replete to nutrientdepleted conditions (see also Engel et al., 2015). That is in line with previous studies (Engel et al., 2002; Conan et al., 
2007; Carlson and Hansell, 2015) showing DOM accumulation after the onset of nutrient limitation, while the chl $a$ signal decreased.

The effect of initial nutrient concentrations on DOC accumulation (Fig. 5a, b), observed in our study, was shown previously. In a mesocosm study with ETNA waters, Franz et al. (2012) observed that higher DOC concentrations developed when the initial inorganic nitrogen supply was high. As well, DOC concentrations in their study were even higher when high DIN concentrations were combined with high DIP supply. In their mesocosm experiment in Raunefjord, Conan et al. (2007) and Stedmon and Markager (2005) observed that at silicate-replete conditions, DOC concentrations under high initial DIN supply did not vary significantly from those under high initial DIP concentrations. In our study, silicate was also not limiting phytoplankton growth and higher DOC concentrations occurred at higher DIP as well as at higher DIN concentrations, supporting earlier findings.

Bacterial turnover may have influenced the composition of DOM (as it is seen by changes in spectral slope ratios and FDOM components) while DOC concentrations seemed to be not related to bacterial abundances. This observation may be explained by rapid bacterial consumption of labile DOM accompanied by the bacterial release of altered humiclike DOM (Azam et al., 1983; Ogawa et al., 2001), which are therefore not influencing measured DOC concentrations (e.g., Kirchman et al., 1991).

At the beginning of the experiment, CDOM absorption coefficients were in the range of those previously reported for open waters of the Atlantic Ocean, while the final CDOM absorptions were twice as high (Fig. S1c, d; Andrew et al., 2013; Nelson and Siegel, 2013). Similar to our experiments, CDOM absorption was previously shown to accumulate by a factor of 2 during mesocosm studies, such as the study by Pavlov et al. (2014), where nutrient levels for DIN were kept at $5 \mu \mathrm{mol} \mathrm{L}{ }^{-1}$ and at $0.32 \mu \mathrm{mol} \mathrm{L}-1$ for DIP.

In our experiments, the accumulation of CDOM during the phytoplankton bloom (Fig. 2c, d) as well as significant covariance to phytoplankton pigment $-\operatorname{chl} a$-concentration suggests that phytoplankton was the major source of CDOM. This is consistent with previous studies that show CDOM to be produced by extracellular release from phytoplankton (Romera-Castillo et al., 2010) or by phytoplankton degradation or lysis (Hu et al., 2006; Zhang et al., 2009; Organelli et al., 2014).

The decrease of CDOM spectral slopes over time (Fig. 2e, f) along with the increase in CDOM concentrations (Fig. 3) indicated that absorption in the visible wavelength range increased relatively to the UV wavelength range. As the absorption at longer wavelength is corresponding to larger molecules, we may assume that HMW-CDOM accumulated during both experiments. HMW-DOM was previously shown to be more labile for bacterial consumption than low molecular weight DOM (at molecular weight cutoff of $1 \mathrm{kDa}$; Benner and Amon, 2015), as bacterial activity was higher, when incubating with HMW-DOM (Amon and Benner, 1996). Furthermore, HMW-DOM typically accounts for 30 to $60 \%$ of the total DOM released via phytoplankton (Biddanda and Benner, 1997; Engel et al., 2011). Therefore, we consider the spectral slope decrease over time as an indication of labile CDOM production via phytoplankton release.

In treatments with high initial DIN concentrations, bacterial abundance was significantly higher than in those with lower initial DIN concentrations. Furthermore, bacterial abundances in Varied $\mathrm{N}$ correlated significantly to CDOM concentrations. We therefore suggest that higher bacterial abundance may have been responsible for an additional production of CDOM in mesocosms, particularly in those with high initial DIN supply.

This suggestion is made also based on changes in optical properties during our study. As Helms et al. (2008) and Zhang et al. (2009) showed before, the spectral slope ratio $S_{\mathrm{R}}$ - decreases when bacterial modification of CDOM takes place. A slight decrease of $S_{\mathrm{R}}$ towards the end of Varied $\mathrm{N}$ (Fig. 2h), most likely indicated that CDOM was reworked by bacteria. Our conclusion of additional CDOM production by bacteria in this experiment is also in agreement with previous studies, where DOM bacterial reworking was indicated as CDOM source (Rochelle-Newall and Fisher, 2002; Kramer and Herndl, 2004; Nelson et al., 2004; Biers et al., 2007; Swan et al., 2009; Nelson and Siegel, 2013).

However, due to its large uncertainties within treatments, $S_{\mathrm{R}}$ was not sufficient to estimate the degree of bacterial CDOM production, most likely due to screening of the effect by simultaneous high HMW-DOM production via phytoplankton release. Therefore, CDOM production via phytoplankton release, which occurred proportionally to phytoplankton biomass, was likely more pronounced than CDOM production via bacterial reworking of labile DOM.

The CDOM to DOC ratio was also affected by variable initial DIN concentrations. A significant positive correlation of CDOM accumulation over time with DOC concentration was found in both experiments (Fig. 6a, b), indicating that DOC and CDOM had been affected by the same processes. Estimated slopes of $\triangle \mathrm{CDOM}$ against $\triangle \mathrm{DOC}$ (Fig. 6d), in Varied N, were highest at the highest initial DIN concentrations, indicating that relative proportion of CDOM in bulk DOM may be regulated by the presence of DIN.

Factors influencing the ratio between CDOM absorption and DOC concentrations are not well-understood so far. It is known that CDOM absorption often co-varies with DOC concentration in river estuaries and coastal seas, which are influenced to a high degree by conservative mixing of riverine and marine waters (Nelson and Siegel, 2013; RochelleNewall et al., 2014). However, in the open ocean, the relation is losing its consistency (Nelson and Siegel, 2013). We suggest that under higher initial DIN concentrations bacterial abundance is higher and such is the bacterial reworking of DOM. Higher bacterial reworking, in turn, causes an increase in the proportion of the colored fraction in DOM. Our 
results suggest that an increase of initial DIN concentrations by $10 \mu \mathrm{mol} \mathrm{L}{ }^{-1}$ would cause an increase in CDOM accumulation $\left(\triangle a_{\mathrm{CDOM}}(325)\right)$ by $1.4 \times 10^{-3} \mathrm{~m}^{-2} \mathrm{mmol}^{-1}$ (see Fig. 6d) relative to accumulation of DOC $(\triangle D O C)$. The change, however, is small compared to those caused by other factors, as, for instance, mixing and photochemical oxidation (Stedmon and Nelson, 2015). Nonetheless, the effect may be important in regimes or at times where or when changes of DIN concentrations are high.

When CDOM properties, such as spectral slopes $S_{275-295}$, were also taken into account, the variance of relationship between CDOM and DOC between treatments was not as apparent (Fig. 6e). We found a good correspondence between $S_{275-295}$ and $a_{\mathrm{CDOM}}(325) / \mathrm{DOC}$ ratio during our study, which could be explained by Eq. (3). Our data suggest that the stable $S_{275-295}$ to $a_{\mathrm{CDOM}}(325)$ / DOC relationship could be used for DOC estimation in the open ocean, when $S_{275-295}$ and $a_{\mathrm{CDOM}}(325)$ are known, as, for instance, in field studies, where optical sensors are used. For remote sensing, however, an application of this relationship would be rather difficult, since ocean color remote-sensing measurements are limited to an "optical window" of visible to near-infrared wavelength range (Robinson, 2010).

Besides absorption, FDOM fractions were more sensitive to nutrient amendments. During our study, three different fluorescent components could be identified (Fig. 4).

The characteristics of the first component, Comp.1 (Table 3), were similar to those of the humic-like peak "A" described by Coble et al. (1996). The Comp.1 fluorescence was within the reported range of A-like peak fluorescence intensities for the open-ocean area (Jørgensen et al., 2011) or slightly higher towards the end of experiments depending on mesocosm treatment (Fig. S1i, j).

Marine humic substances were previously assigned to bacterially derived substances due to significant covariance of their concentrations to apparent oxygen utilization in deep open-ocean waters (Swan et al., 2009; Kowalczuk et al., 2013; Nelson and Siegel, 2013). As well, previous studies of Stedmon and Markager (2005), Kowalczuk et al. (2009) and Zhang et al. (2009) showed that humic-like components, similar in terms of spectral properties to Comp.1, were produced via microbial DOM reworking (Table 3).

In our study, in Varied N, Comp.1 was strongly correlated to initial DIN concentrations, as the final Comp. 1 fluorescence intensity was almost three fold higher at the highest initial DIN supply than that in the treatments with lowest DIN supply. Thus, since bacterial abundance was DINdependent in this experiment and Comp. 1 fluorescence intensities correlated significantly to bacterial abundances, the bacteria were likely responsible for Comp.1 occurrence during our experiments. The observed bacterial production of humic-like Comp. 1 that is proportional to DIN is in agreement with Kramer and Herndl (2004) and Biers et al. (2007), where DIN and its organic derivatives were considered to be the primary drivers of humic-like DOM accumulation via bacterial reworking.

In Varied P, however, Comp.1 was not related to bacterial abundance. No significant differences between treatments were noticed for bacterial abundance and only few differences occurred for Comp. 1 at similar initial DIN supply concentrations. Thus, under equal initial DIN concentrations bacterial reworking of DOM could occur at a similar degree, causing the absence of covariance of Comp.1 with bacterial abundance.

The higher concentrations of Comp. 1 at the end of our experiments compared to concentrations measured in open ocean (Jørgensen et al., 2011) may be explained by slightly higher substrate availability in the mesocosms than that in the North Atlantic.

The fluorescence properties of the second FDOM component, Comp.2 (Table 3), were similar to that of the previously defined amino acid-like fluorescence (Mopper and Schulz, 1993; Coble et al., 1996; Stedmon and Markager, 2005): tryptophan-like peak "T" (Coble et al., 1996). The fluorescence intensities of this component were in the range of that previously reported for open-ocean area (Jørgensen et al., 2011) for the whole experimental period (Fig. S1k, 1).

Similar in terms of spectral properties to Comp.2, amino acid-like compounds were previously hypothesized to represent the fluorescence of the bound-to-protein matrix amino acids tryptophan and tyrosine (Stedmon and Markager, 2005) and were assumed to be produced by phytoplankton (Mopper and Schulz, 1993; Coble et al., 1996). We, therefore, consider Comp. 2 as an indicator of phytoplankton-produced proteinaceous DOM and as a possible precursor for humic-like FDOM.

In Varied P, Comp. 2 accumulated proportionally to initial DIP concentrations and its concentration did not correspond to chl $a$ concentration. This might indicate that proteinaceous DOM release by phytoplankton is controlled by nutrient availability, rather than by phytoplankton biomass itself, i.e., proteinaceous DOM is produced as a part of an "overflow mechanism" (Wood and Van Valen, 1990) of extracellular release.

In Varied N, again no covariance of Comp. 2 to chl $a$ was determined. However, a covariance of Comp. 2 with initial DIN concentrations did not occur as well. As bacteria were more abundant in treatments with higher initial DIN supply and also Comp. 2 intensities revealed significant correspondence to bacteria, we suggest that bacterial reworking may have regulated Comp. 2 fluorescence intensities, particularly under high initial DIN concentrations.

Previously, Stedmon and Markager (2005) showed an accumulation of an FDOM component, with spectral properties similar to Comp.2, during their mesocosm study treatments of high DIN and high DIP concentrations. This component was also shown to be consumed during dark and light incubations, when bacteria were added. Kirchman et al. (1991) showed that DOM uptake can be accompanied by a decrease 
in DIN concentrations, indicating the importance of DIN presence during bacterial reworking of labile DOM. Therefore, Comp. 2 production might be dependent on initial DIP and DIN availability, similar to the increase of DOC concentrations. As well as at high initial DIN concentrations, Comp. 2 may serve a substrate for developing bacteria, i.e., it can be consumed by bacteria that, in their turn, release humic-like Comp.1.

The spectral properties of the third fluorescent component - Comp. 3 - were similar to that of amino acid-like fluorescence (Table 3; Mopper and Schulz, 1993; Coble et al., 1996; Stedmon and Markager, 2005): tyrosine-like peak "B" (Coble et al., 1996) and were in the range of those previously reported for open-ocean area (Jørgensen et al., 2011; Fig. S1m, n).

The development patterns as well as no clear response towards nutrient amendments of Comp. 3 made it very difficult to interpret.

In Varied P, Comp. 3 fluorescence intensities were highest at the day of chl $a$ maximum (Fig. $2 \mathrm{~m}$ ). Thus, Comp. 3 could be released by phytoplankton at the growth phase, while after the chl $a$ maximum, rapid bacterial reworking of DOM or abiotic aggregation to Comp. 2 could remove Comp. 3 from the mesocosms.

In Varied N, Comp.3 fluorescence intensities were generally low, but increased at the end of experiment (Fig. 2n). Therefore, the process of bacterial Comp. 2 reworking could lead to Comp. 3 release as a byproduct at the final stage of Varied N. On the other hand, Comp.3 accumulation towards the end of this experiment could be a result of extracellular release of higher amounts of amino acid-like substances, which accumulated under high DIN concentrations within phytoplankton tissues during its growth.

A fluorescent substance, similar by spectral properties to Comp.3, was previously hypothesized to represent the tryptophan and tyrosine in peptides by Stedmon and Markager (2005), as it had been previously found accumulating during the denaturation of proteins (Determann et al., 1998). In their study, Stedmon and Markager (2005) found no effect of microbial reworking on the abundance of this fluorescence substance in the dark and light incubations with bacteria. However, as this substance was removed during thier mesocosm experiment, they hypothesized spontaneous abiotic aggregation or photochemically induced flocculation as possible removal mechanisms.

We, therefore, conclude that Comp. 3 potentially acted as an intermediate product during the formation or degradation of proteinaceous Comp. 2 in our study. Still, the interpretation of the Comp. 3 development remains speculative.

It was hypothesized previously that phosphorus limitation leads to an accumulation of DOM that is more resistant to microbial degradation (Kragh and Sondergaard, 2009), e.g., due to phytoplankton extracellular release of this "poor quality" DOM or limitation of bacterial DOM consumption (Carlson and Hansell, 2015). Based on changes in optical DOM properties $\left(S_{R}\right.$, Comp.1, Comp.2) in our study, we suggest that labile DOM in the ETNA accumulates proportionally to either DIN or DIP concentrations. However, the "poor quality" DOM accumulates more under high DIN concentrations (i.e., phosphorus limitation), due to bacterial DOM reworking. And even though bacterial activity per cell might have been limited by phosphorus availability, higher bacterial abundance in treatments with higher initial DIN supply would lead to more pronounced net accumulation of more resistant to microbial degradation DOM.

Overall, the variances of CDOM and FDOM concentrations in the treatment with DIN : DIP of $16(12.00 \mathrm{~N} / 0.75 \mathrm{P})$ for each experiment were higher than the variance in this treatment between experiments. Therefore, the effects of nutrients on CDOM and FDOM concentrations were considered much stronger than possible effects caused by differences in initial sensitivity to nutrient additions. However, due to the divergence in development pattern for some of optically active parameters $\left(S_{\mathrm{R}}\right.$, Comp.3), we cannot exclude the difference in pelagic communities during Varied $\mathrm{P}$ and Varied $\mathrm{N}$ from the aspects that can cause an additional CDOM and FDOM variability during our study.

Another important aspect that could cause an additional CDOM and FDOM variability, and, therefore, bias the interpretation of obtained results during the mesocosm experiments, is the length of the sample storage. In our study, CDOM and FDOM samples were filtered through $0.45 \mu \mathrm{m}$ pore-size filters and stored in the dark and cold $\left(+4^{\circ} \mathrm{C}\right)$ for approximately 6 months pending analyses due to logistical reasons. This time period is long and CDOM and FDOM concentrations could be affected by remaining bacteria during storage. The long-term storage of open-ocean CDOM samples has been tested previously by Swan et al. (2009). They demonstrated that CDOM changes are unappreciable, when the storage of pre-filtered CDOM samples at $4{ }^{\circ} \mathrm{C}$ does not exceed 1 year. Furthermore, during our study, FDOM samples from all the mesocosms were measured for day 4 of each experiment (31 samples in total) at approximately 3 months after main set of measurements had been accomplished. No drastic or appreciable changes in FDOM components concentrations had been noticed as they developed, e.g., neither between replicates, nor between treatments. Therefore, despite the pore-sizes of our filters were larger than those used by Swan et al. (2009), we believe that due to generally low CDOM and FDOM concentrations the error that could occur would not majorly influence CDOM and FDOM development patterns during our observations.

\section{Conclusions}

Our study shows that during phytoplankton blooms DOM is largely derived from phytoplankton, while its optical properties undergo considerable changes due to bacterial reworking. Thus, optically active proteinaceous substances are 
freshly produced by phytoplankton release. They are, however, consumed and reworked by bacteria, leading to an accumulation of less-bioavailable optically active humic substances.

Our experiments indicate that DIN is the major macronutrient regulating the accumulation of bacterially originated optically active humic substances, while the accumulation of labile proteinaceous substances via phytoplankton is rather regulated by DIN and DIP. An input of humic substances can increase the CDOM/DOC ratio and therewith affect predictions of DOC concentration based on CDOM absorption. Still, a relationship between CDOM spectral properties and CDOM and DOC concentrations can be derived, which is not influenced by differences in the nutrient supply.

\section{The Supplement related to this article is available online at doi:10.5194/bg-12-6897-2015-supplement.}

Acknowledgements. This study was supported by the SFB754 project, "Climate-Biogeochemical Interactions in the Tropical Ocean" of the DFG. We thank all participants of our Cabo Verde 2012 research stay for joint work during water sampling and handling of mesocosms and also N. Vieira for help with initial water sampling. We also thank I. Monteiro, M. Schütt and P. Silva for help with logistics.

We are very grateful to $P$. Kowalczuk for valuable comments during our PARAFAC analysis, J. Roa for DOC analyses, U. Pankin for nutrient measurements, and S. Endres, L. Galgani, R. Flerus and C. Löscher for helpful discussions during the manuscript writing. We are very thankful also to P. Kowalczuk and an anonymous referee for reviewing and commenting on the manuscript, as well as to M. Mostofa for his short comment on the manuscript.

All data will be available at www.pangaea.de upon publication of the manuscript.

The article processing charges for this open-access publication were covered by a Research

Centre of the Helmholtz Association.

Edited by: G. Herndl

\section{References}

Amon, R. M. W. and Benner, R. Bacterial utilization of different size classes of dissolved organic matter, Limnol.Oceanogr., 41, 41-51, 1996.

Andrew, A. A., Del Vecchio, R., Subramaniam, A., and Blough, N. V.: Chromophoric dissolved organic matter (CDOM) in the Equatorial Atlantic Ocean: Optical properties and their relation to CDOM structure and sourse, Mar. Chem., 148, 33-43, 2013.

Azam, F., Fenchel, T., Field, J. G., Gray, J. S., Meyer-Reil, L. A., and Thingstad, F.: The ecological role of water-column microbes in the sea, Mar. Ecol.-Prog. Ser., 10, 257-263, 1983.
Benner, R. and Amon, RMW.: The size-reaktivity continuum of major bioelements in the ocean, Annu. Rev. Mar. Sci., 7, 2.1-2.21, 2015.

Biddanda, B. and Benner, R.: Carbon, nitrogen and carbohydrate fluxes during the production of particulate and dissolved organic matter by marine phytoplankton, Limnol. Oceanogr., 42, 506518, 1997.

Biers, E. J., Zepp, R. G., Moran, M. A.: The role of nitrogen in chromophoric and fluorescent dissolved organic matter formation, Mar. Chem., 103, 46-60, 2007.

Brandt, P., Bange, H. W., Banyte, D., Dengler, M., Didwischus, S.-H., Fischer, T., Greatbatch, R. J., Hahn, J., Kanzow, T., Karstensen, J., Körtzinger, A., Krahmann, G., Schmidtko, S., Stramma, L., Tanhua, T., and Visbeck, M.: On the role of circulation and mixing in the ventilation of oxygen minimum zones with a focus on the eastern tropical North Atlantic, Biogeosciences, 12, 489-512, doi:10.5194/bg-12-489-2015, 2015.

Bricaud, A., Morel, A., and Prieur L.: Absorption by dissolved organic matter of the sea (yellow substance) in the UV and visible domain, Limnol. Oceanogr., 26, 43-53, 1981.

Carlson, C. A. and Hansell, D. A.: DOM sourses, sinks, reactivity and budgets, In Biogeochemistry of marine dissolved organic matter 2nd ed., edited by: Hansell, D. A. and Carlson, C. A., Elsevier, 66-109, 2015.

Coble, P. G.: Characterisation of marine and terrestrial DOM in seawater using excitation-emission matrix spectroscopy, Mar. Chem., 51, 325-346, 1996.

Coble, P. G: Marine optical biogeochemistry: The chemistry of ocean color, Chem. Rev., 107, 402-418, doi:10.1021/cr050350+, 2007.

Conan, P., Søndergaard, M., Kragh, T., Thingstad, F., Pujo-Pay, M., Williams, P.J. le B., Markager, S., Cauwet, G., Borch, N. H., Evans, D., and Riemann, B.: Partitioning of organic production in marine plankton communities: The effects of inorganic nutrient ratios and community composition on new dissolved organic matter, Limnol. Oceanogr., 52, 753-765, 2007.

De Haan, H. and De Boer, T.: Applicability of light absorbance and fluorescence as measures of concentration and molecular size of dissolved organic carbon in humic Laken Tjeukemeer, Water Res., 21, 731-734, 1987.

Del Castillo, C. E.: Remote sensing of organic matter in coastal waters, In "Remote sensing of coastal aquatic Environments: Technologies, techniques and applications", edited by: Miller, R. L., Del Castillo, C. E., and McKnee, B. A., Springer, 157-180, 2007.

Del Vecchio, R. and Blough, N. V.: On the origin of the optical properties of humic substances, Environ. Sci. Technol., 38, 38853891, 2004.

Determann, S., Lobbes, J. M., Reuter, R., and Rullköter, J.: Ultraviolet fluorescence excitation and emission spectroscopy of marine algae and bacteria, Mar. Chem., 62, 137-156, 1998.

Engel, A., Goldthwait, S., Passow, U., and Alldredge A.: Temporal decoupling of carbon and nitrogen dynamics in a mesocosm diatom bloom, Limnol. Oceanogr., 47, 753-761, 2002.

Engel, A., Händel, N., Wohlers, J., Lunau, M., Grossart, H.-P-, Sommer, U., and Riebesell, U.: Effects of sea surface warming on the production and consumption of dissolved organic matter during phytoplankton blooms: results from a mesocosm study, J. Pankton Res., 33, 357-372, 2011. 
Engel, A., Borchard, C., Loginova, A., Meyer, J., Hauss, H., and Kiko, R.: Effects of varied nitrate and phosphate supply on polysaccharidic and proteinaceous gel particle production during tropical phytoplankton bloom experiments, Biogeosciences, 12, 5647-5665, doi:10.5194/bg-12-5647-2015, 2015.

Fanning, K. A.: Nutrient provinces in the sea: Concentration ratios, and ideal covariation, J. Geophys. Res., 97, 5693-5712, 1992.

Fichot, C. G. and Benner, R.: A novel method to estimate DOC concentrations from CDOM absorption coefficients in coastal waters, Geophys. Res. Lett., 38, L03610, doi:10.1029/2010GL046152, 2011.

Fichot, C. G. and Benner, R.: The spectral slope coefficient of chromophoric dissolved organic matter $\left(S_{275-295}\right)$ as a tracer of terrigenous dissolved organic carbon in riverinfluenced ocean margins, Limnol. Oceanogr., 57, 1453-1466, doi:10.4319/lo.2012.57.5.1453, 2012.

Franz, J. M. S., Hauss, H., Sommer, U., Dittmar, T., and Riebesell, U.: Production, partitioning and stoichiometry of organic matter under variable nutrient supply during mesocosm experiments in the tropical Pacific and Atlantic Ocean, Biogeosciences, 9, 46294643, doi:10.5194/bg-9-4629-2012, 2012.

Granskog, M. A., Macdonald, R. W., Mundy, C. J., and Barber, D. G.: Distribution, characteristics and potential impacts of chromophoric dissolved organic matter (CDOM) in Hudson Strait and Hudson Bay, Canada, Cont. Shelf Res., 27, 2032-2050, 2007.

Gruber, N. and Sarmento, J. L.: Global patterns of marine nitrogen fixation and denitrification, Global Biogeochem. Cy., 11, 235266, 1997

Guéguen, C. and Kowalczuk, P.: Colored dissolved organic matter in frontal zones, in: Chemical Oceanography of Frontal Zones, edited by: Belkin, I., Springer Verlag, doi:10.1007/698_2013_244, 2013.

Hansell, D. A., Carlson, C. A., Repeta, D. J., and Shitzer, R.: Dissolved organic matter in the ocean: a controversy stimulated new insights, Oceanography, 22, 202-211, 2009.

Hauss, H., Franz, J. M. S., Hansen, T., Struck, U., and Sommer, U.: Relative inputs of upwelled and atmospheric nitrogen to the eastern tropical North Atlantic food web: Spatial distribution of $\delta^{15} \mathrm{~N}$ in meso zooplankton and relation to dissolved nutrient dynamics, Deep-Sea Res. Pt. I, 75, 135-145, doi:10.1016/j.dsr.2013.01.010, 2013.

Helms, J. R., Stubbins, A., Ritchie, J. D., and Minor, E. C.: Absorption spectral slopes and slope ratios as indicators of molecular weight, source, and photobleaching of chromophoric dissolved organic matter, Limnol. Oceanogr., 53, 955-969, 2008.

Hu, C., Lee, Z., Muller-Karger, F. E., Carder, K. L., and Walsh, J. J.: Ocean color reveals phase shift between marine plants and yellow substance, IEEE Geosci. Remote S., 3, 262-266, 2006.

Ishii, S. K. L. and Boyer, T. H.: Behavior of Reoccurring PARAFAC Components in Fluorescent Dissolved Organic Matter in Natural and Engineered Systems: A Critical Review, Environ. Sci. Technol. 46, 2006-2017, doi:10.1021/es2043504, 2012.

Jayakumar, A., O’Mullan, G. D., Naqvi, S. W. A., and Ward, B. B.: Denitrifying Bacterial Community Composition Changes Associated with Stages of Denitrification in Oxygen Minimum Zones, Microb. Ecol., 58, 350-362, doi:10.1007/s00248-009-9487-y, 2009.
Jetten, M. S., Niftrik, L., Strous, M., Kartal, B., Keltjens, J. T., and Op den Camp, H. J.: Biochemistry and molecular biology of anammox bacteria, Crit. Rev. Biochem. Mol., 44, 65-84, doi:10.1080/10409230902722783, 2009.

Jiao, N., Herndl, G. J., Hansell, D. A., Benner, R., Kattner, G., Wilhelm, S. W., Kirchman, D. L., Weinbauer, M. G., Luo, T., Chen, F., and Azam, F.: Microbial production of recalcitrant dissolved organic matter: long-term carbon storage in the global ocean, Nat. Rev. Microbiol., 8, 593-599, doi:10.1038/nrmicro2386, 2010.

Jørgensen, L., Stedmon, C.A., Kragh, T., Markager, S., Middelboe, M., and Søndergaard, M.: Global trends in the fluorescence characteristics and distribution of marine dissolved organic matter, Mar. Chem., 126, 139-148, doi:10.1016/j.marchem.2011.05.002, 2011.

Karstensen, J., Stramma, L., and Visbeck, M.: Oxygen minimum zones in the eastern tropical Atlantic and Pacific oceans, Progr. Oceanogr., 77, 331-350, doi:10.1016/j.pocean.2007.05.009, 2008.

Karstensen, J., Fiedler, B., Schütte, F., Brandt, P., Körtzinger, A., Fischer, G., Zantopp, R., Hahn, J., Visbeck, M., and Wallace, D.: Open ocean dead zones in the tropical North Atlantic Ocean, Biogeosciences, 12, 2597-2605, doi:10.5194/bg-12-2597-2015, 2015.

Kartal, B., Kuypers, M. M., Lavik, G., Schalk, J., Op den Camp, H. J., Jetten, M. S., and Strous, M.: Anammox bacteria disguised as denitrifiers: nitrate reduction to dinitrogen gas via nitrite and ammonium, Environ. Microbiol., 9, 635-642, 2007.

Kieber, R. J., Zhou, X., and Mopper K.: Formation of carbonyl compounds from UV-induced photodegradation of humic substances in natural waters: fate of riverine carbon in the sea, Limnol. Oceanogr., 35, 1503-1515, 1990.

Kieber, R. J., Li, A., and Seaton, P. J.: Production of nitrite from photodegradation of dissolved organic matter in natural waters, Environ. Sci. Technol., 33, 993-998, 1999.

Kirchman, D. L., Suzuki, Y., Garside, C. and Duklow, H. W.: High turnover rates of dissolved organic carbon during a spring phytoplankton bloom, Letters to Nature, 325, 612-614, 1991.

Kowalczuk, P., Durako, M. J., Young, H., Kahn, A. E., Cooper, W. J., and Gonsior, M.: Characterisation of dissolved organic matter fluorescence in the South Atlantic Bight with the use of PARAFAC model: interannual variability, Mar. Chem., 113, 182-196, 2009.

Kowalczuk, P., Tilstone, G. H., Zablocka, M., Röttgers, R., and Thomas, R.: Composition of dissolved organic matter along and Atlantic Meridional Transect from fluorescence spectroscopy and Parallel Factor Analysis, Mar. Chem., 157, 170-184, 2013.

Kragh, T. and Sondergaard, M.: Production and decomposition of new DOC by marine plankton communities: carbohydrates, refractory components and nutrient limitation, Biogeochemistry, 96, 177-187, 2009.

Kramer, G. D. and Herndl, G. J.: Photo- and bioreactivity of chromophoric dissolved organic matter produced by marine bacterioplankton, Aquat. Microb. Ecol., 36, 293-246, 2004.

Mathis, J. T., Pickart, R. S., Hansell, D. A., Kadko, D., and Bates N. R.: Eddy transport of organic carbon and nutrients from the Chukchi Shelf: impact on the upper halocline of the western Arctic Ocean, J. Geophys. Res., 112, C05011, doi:10.1029/2006JC003899, 2007. 
McGillicuddy Jr., D. J., Anderson, L. A., Doney S. C., and Maltrud M. E.: Eddy-driven sources and sinks of nutrients in the upper ocean: result from a $0.1^{\circ}$ resolution model of the north Atlantic, Global Geochem. Cy., 17, 1035-1055, doi:10.1029/2002GB001987, 2003.

McGillicuddy Jr., D. J., Anderson, L. A., Bates, N. R., Bibby, T., Buesseler, K. O., Carlson, C. A., Davis, C. S., Ewart, C., Falkowski, P. G., Goldthwait, S. A., Hansell, D. A., Jenkins, W. J., Johnson, R., Kosnyrev, V. K., Ledwell, J. R., Li, Q. P., Siegel, D. A., and Steinberg, D. K.: Eddy/wind interactions stimulate extraordinary mid-ocean plankton blooms, Science, 316, 1021-26, doi:10.1126/science.1136256, 2007.

Mopper, K. and Schultz, C. A.: Fluorescence as possible tool for studying the nature of water column distribution of DOC components, Mar. Chem., 41, 229-238, 1993.

Mopper, K., Stubbins, A., Ritchie, J. D., Bialk, H. M., and Hatcher, P. G.: Advanced instrumental approaches for characterization of marine dissolved organic matter: Extraction techniques, mass spectrometry, and nuclear magnetic resonance spectroscopy, Chem. Rev., 107, 419-442, doi:10.1021/cr050359b, 2007.

Moran, M. A. and Zepp, R. G.: Role of photoreactions in the formation of biologically labile compounds from dissolved organic matter, Limnol. Oceanogr., 42, 1307-1316, 1997.

Murphy, K. R., Stedmon C. A., Graeber, D., and Bro, R.: Fluorescence spectroscopy and multy-way techniques. PARAFAC, Anal. Methods, 5, 6557-6566, doi:10.1039/c3ay41160e, 2013.

Nelson, N. B. and Siegel, D. A.: The Global Distribution and Dynamics of Chromophoric Dissolved Organic Matter, Annu. Rev. Mar. Sci., 5, 447-476, doi:10.1146/annurev-marine-120710$100751,2013$.

Nelson, N. B., Siegel, D. A., and Steinberg, D. K.: Production of dissolved organic matter by Sargasso Sea microbes, Mar. Chem., 89, 273-287, doi:10.1016/j.marchem.2004.02.017, 2004.

Nelson, N. B., Siegel, D. A., Carlson, C. A., Swan, C. M., Smethie, W. M., and Khatiwala, S.: Hydrography of chromophoric dissolved organic matter in the North Atlantic, Deep-Sea Res. Pt. I, 54, 710-731, doi:10.1016/j.dsr.2007.02.006, 2007.

Ogawa, H., Amagai, Y., Koike, I., Kaiser, K., and Benner, R.: Production of refractory dissolved organic matter by bacteria, Science, 292, 917-920, 2001.

Organelli, E., Bricaud, A., Antoine, D., and Matsuoka, A.: Seasonal dynamics of light absorption by chromophoric dissolved organic matter (CDOM) in the NW Mediterranean Sea (BOUSSOLE site), Deep-Sea Res. Pt. I, 91, 72-85, doi:10.1016/j.dsr.2014.05.003, 2014.

Parsons, T. R., Maita, Y., and Lalli, C. M.: A manual of chemical and biological methods for seawater analysis, Pergamon Press Oxford, UK, 173 pp., 1984.

Pavlov, A.K., Silyakova, A., Granskog, M.A., Bellerby, R.G.J., Engel, A., Schulz, K.G., and Brussaard, C.P.D.: Marine CDOM accumulation during a coastal Arctic mesocosm experiment: No response to elevated $p \mathrm{CO}_{2}$ levels, J. Geophys. Res., 119, 12161230, doi:10.1002/2013JG002587, 2014.

Redfield, A. C.: The biological control of chemical factors in the environment, Am. Sci., 46, 205-221, 1958.

Robinson, I. S.: Discovering the ocean from space: The unique applications of satellite oceanography, Springer, 7-66, 2010.

Rochelle-Newall, E. J. and Fisher, T. R.: Production of chromophoric dissolved organic matter fluorescence in marine and estuarine environments: An investigation into the role of phytoplankton, Mar. Chem., 77, 7-21, 2002.

Rochelle-Newall, E. J., Hulot, F. D., Janeau, J. L., and Merroune, A.: CDOM fluorescence as a proxy of DOC concentration in natural waters: a comparison of four contrasting tropical systems, Environ. Monit. Assess., 186, 589-596, doi:10.1007/s10661013-3401-2, 2014.

Romera-Castillo, C., Sarmento, H., Álvarez-Salgado, X. A., Gasol, J. M., and Marrase C.: Production of chromophoric dissolved organic matter by marine phytoplankton, Limnol. Oceanogr., 55 , 446-454, 2010.

Stedmon, C. A. and Álvarez-Salgado, X. A.: Shedding Light on a Black Box: UV-Visible Spectroscopic Characterization of Marine Dissolved Organic Matter, in: Microbial Carbon Pump, edited by: Jiao, N. and Azam, F., Senders, 62-63, 2011.

Stedmon, C. A. and Bro, R.: Characterizing dissolved organic matter fluorescence with parallel factor analysis: a tutorial, Limnol. Oceanogr.-Methods, 6, 572-579, doi:10.4319/lom.2008.6.572, 2008.

Stedmon, C. A. and Markager, S.: The optics of chromophoric dissolved organic matter (CDOM) in the Greenland Sea: An algorithm for differentiation between marine and terrestrially derived organic matter, Limnol. Oceanogr., 46, 2087-2093, 2001.

Stedmon, C. A. and Markager S.: Tracing the production and degradation of autochtonous fractions of dissolved organic matter by fluorescence analysis, Limnol. Oceanogr., 50, 1415-1426, 2005.

Stedmon, C. A. and Nelson, N.: The optical properties of DOM in the ocean, In Biogeochemistry of marine dissolved organic matter 2nd ed., edited by: Hansell, D. A. and Carlson, C. A., Elsevier, 481-503, 2015.

Stedmon, C. A., Amon, R. M. W., Rinehart, A. J., and Walker, S. A.: The supply and characteristics of colored dissolved organic matter (CDOM) in the Arctic Ocean: Pan Arctic trends and differences, Mar. Chem., 124, 108-118, 2011.

Strous, M., Pelletier, E., Mangenot, S., Rattei, T., Lehner, A., Taylor, M. W., Horn, M., Daims, H., Bartol-Mavel, D., Wincker, P., Barbe, V., Fonknechten, N., Vallenet, D., Segurens, B., Schenowitz-Truong, C., Médigue, C., Collingro, A., Snel, B., Dutilh, B. E., Op den Camp, H. J. M., van der Drift, C., Cirpus, I., van de Pas-Schoonen, K. T., Harhangi, H .R., Lan Niftrik, L., Schmid, M., Keltjens, J., van de Vossenberg, J., Kartal, B., Meier, H., Frishman, D., Huynen, M. A., Mewes, H.-W., Weissenbach, J., Jetten, M. S. M., Wagner, M., and Le Paslier, D.: Deciphering the evolution and metabolism of an anammox bacterium from a community genome, Nature, 440, 790-794, doi:10.1038/nature04647, 2006.

Sugimura, Y. and Suzuki, Y.: A high-temperature catalytic oxidation method for the determination of non-volatile dissolved organic carbon in seawater by direct injection of a liquid sample, Mar. Chem., 24, 105-131, 1988.

Sulzberger, B. and Durisch-Kaiser, E.: Chemical characterization of dissolved organic matter (DOM): A prerequisite for understanding UV-induced changes of DOM absorption properties and bioavailability, Aquat. Sci., 71, 104-126, doi:10.1007/s00027008-8082-5, 2009.

Swan, C. M., Siegel, D. A., Nelson, N. B., Carlson, C. A., and Nasir, E.: Biogeochemical and hydrographic controls on chromophoric dissolved organic matter distribution in the Pacific Ocean, Deep- 
Sea Res. Pt. I, 56, 2172-2192, doi:10.1016/j.dsr.2009.09.002, 2009.

Swan, C. M., Nelson, N. B., Siegel, D. A., and Fields, E. A.: A model for remote estimation of ultraviolet absorption by chromophoric dissolved organic matter based on global distribution of spectral slope, Remote Sens. Environ., 136, 277-285, doi:10.1016/j.rse.2013.05.009, 2013.

Wood, A. and Van Valen, L.: Paradox lost? On release of energyrich compounds by phytoplankton, Mar. Microb., 4, 103-116, 1990.

Yamashita, Y., Jaffe, R., Maie, N., and Tanoue, E.: Assessing the dynamics of dissolved organic matter (DOM) in coastal environments by excitation emission matrix fluorescence and parallelfactor analysis (EEM-PARAFAC), Limnol. Oceanogr., 53, 19001908, 2008.
Yamashita, Y., Cory, R.M., Nishioka, J., Kuma, K., Tanoue, E., and Jaffé, R.: Fluorescence characteristics of dissolved organic matter in the deep waters of Okhotsk Sea and northweastern North Pacific Ocean, Deep-Sea Res. Pt. II, 57, 1478-1485, doi:10.1016/j.dsr2.2010.02.016, 2010.

Zepp, R. G., Shank, G. C., Stabenau, E., Patterson, K. W., Cyterski, M. J., Fisher, W. S., Bartels, E., and Anderson S. L.: Spatial and temporal variability of solar ultraviolet exposure of coral assemblages in the Florida Keys: Importance of Colored Dissolved Organic Matter, Limnol. Oceanogr., 53, 1909-1922, 2008.

Zhang, Y., van Dijk, M. A., Liu, M., Zhu, G., and Qin, B.: The Contribution of phytoplankton degradation to chromophoric dissolved organic matter (CDOM) in eutrophic shallow lakes: Field and experimental evidence, Water Res., 43, 4685-4697, doi:10.1016/j.watres.2009.07.024, 2009. 